Chapter 9

\title{
Organic Tuber Production is Promising - Implications of a Decade of Research in India
}

\author{
Suja Girija, Sreekumar Janardanan, Jyothi Alummoottil Narayanan and \\ Santosh Mithra Velayudhan Santhakumari \\ Additional information is available at the end of the chapter
}

http://dx.doi.org/10.5772/61846

\begin{abstract}
Alternative soil management practices like organic farming assume significance in the context of climate change for safe food production. Yams (white yam, greater yam and lesser yam) and edible aroids (elephant foot yam (EFY), taro and tannia) are tuberous vegetables with good taste and nutritive value. Six field experiments were conducted at the ICAR-Central Tuber Crops Research Institute, Thiruvananthapuram, India, over a decade (2004-2015) to compare the varietal response, yield, quality and soil properties under organic vs conventional system and develop a learning system. The elite and local varieties of EFY and taro and the three species of yams, including trailing and dwarf genotypes, responded equally well to both the systems. Organic management enhanced the yield by $10-20 \%$ and the net profit by $20-40 \%$ over chemical farming. The tuber quality was improved with higher dry matter, starch, crude protein, $\mathrm{K}, \mathrm{Ca}$ and $\mathrm{Mg}$ contents. The anti-nutritional factor in EFY, oxalate content, was lowered by $21 \%$. Physico-chemical and biological properties of soil were favoured and the organic system scored a significantly higher soil quality index. The cost-effective technologies were field validated. A learning system developed using artificial neural networks predicted the performance of EFY organic production system.
\end{abstract}

Keywords: Eco-friendly farming, root crops, yield, quality, soil health, learning system

\section{Introduction}

Worldwide concerns regarding food safety, environmental degradation and threats to human health have aroused interest in alternative sustainable agricultural systems [1]. "Land degradation" is considered to be one of the world's greatest environmental challenges as per the UN millennium ecosystem assessment. Globally, $40 \%$ of the arable land is seriously degraded and 
$11 \%$ of this is situated in Asia [2, 3]. The land quality for food production ensures future peace. "Organic farming" is a viable option that enables sustainable production, maintenance of soil health, protection of human health and conservation of environment. It envisages non-use of synthetic chemicals, reduced use of purchased inputs and maximum use of on-farm-generated resources [3].

High input conventional agriculture that uses large quantities of chemical inputs and few $\mathrm{C}$ additions silently results in irrevocable ecological and environmental calamities [4, 5]. The necessity for environmental conservation along with the desire for safe foods has made organic farming one of the fastest growing agricultural enterprises [6]. It is well documented that there is a great demand for organic produce because of the belief that organic foods are more nutritious than conventionally grown ones $[3,7]$. However, the nutritional or qualitative superiority of the organic food has yet to be proved conclusively. Reduced energy use and $\mathrm{CO}_{2}$ emissions, employment generation, waste recycling and export promotion are the other merits of organic farming $[3,8,9]$.

Tropical tuber crops constitute important staple or subsidiary food for about 500 million of the global population. Yams (Dioscorea spp.) and aroids are ethnic tuberous vegetables with good taste and medicinal values. They have high content of carbohydrate and are rich in energy. They also have higher protein content and better balance of amino acids than many other root and tuber crops. They are food security crops grown in tropical countries, mainly West Africa, the Caribbean, Pacific Islands and Southeast Asia. Tropical tuber crops in general and edible aroids like EFY, taro and tannia respond well to organic manures. Hence, there is great scope for organic production in these crops [3, 10-14]. There is a great demand for organically produced tuberous vegetables among affluent Asians and Africans living in Europe, USA and Middle East. Research and development on organic farming of tropical tuber crops is less focussed and documented. There is not much documented scientific evidence or information about the effects of organic management on yield, nutritional quality and soil health [3].

\section{Why organic agriculture?}

The major challenge faced by world agriculture is the production of food for a population of nine billion by 2050 , with the anticipated climate change $[15,16]$. There is an urgent call for transformations to increase the productive capacity and stability of smallholder agricultural production systems [15]. There is considerable discussion about the inadequacy of the present system of agricultural intensification and growth, which relies on increased use of capital inputs, such as fertilizers and pesticides $[15,17]$. The generation of unacceptable levels of environmental damage and problems of economic feasibility are cited as key problems [17, 18]. Increasing concerns about the negative impacts of industrial agriculture have led to a serious debate over the feasibility of transition to alternative forms of agriculture, which are capable of providing a broad suite of ecosystem services while producing stable yields for human use [15]. Greater attention is thus being given to alternative models of intensification, and in particular, the potential of sustainable land management technologies. Such practices 
can provide private benefits for farmers, by improving soil fertility and structure, conserving soil and water, enhancing the activity and diversity of soil fauna, and strengthening the mechanisms of nutrient cycling [15]. These benefits can lead to increased productivity and stability of agricultural production systems [19-23] and offer a potentially important means of enhancing agricultural returns and food security as well as reducing the vulnerability of farming systems to climatic risk. Organic agriculture is one such promising alternative.

\section{Organic farming feasible in selected areas and crops in India}

In India, approximately $62 \%$ of cropped area is rain-fed, where there is little or no use of fertilizers and other agro-chemicals due to poor resources with smallholder farmers. Thus, promotion of organic farming in India is advocated initially in these rain-fed areas particularly in the hilly regions of northern and northeastern parts and dry land areas of the country. The Fertilizer Association of India has identified totally about 50 districts in the states of Orissa, Jharkhand, Uttranchal, Himachal Pradesh, Jammu and Kashmir, Rajasthan, Gujarat, Madhya Pradesh and Chhattisgarh as low-fertilizer-consuming districts with the consumption ranging from $1.79 \mathrm{~kg} \mathrm{ha}^{-1}$ to $19.80 \mathrm{~kg} \mathrm{ha}^{-1}$ as against the national average of $90.2 \mathrm{~kg} \mathrm{ha}^{-1}[24,25]$. This means that there is immense scope for organic farming in these selected areas and for selected crops in India, like pulses, oilseeds, tuber crops, etc., for which conventionally little or no fertilizers and agro-chemicals are used. On the other hand, some areas growing tea, coffee, cashew, nuts and spices may be easily brought under organic farming with a thrust on export of organic produce. In other words, rather than promoting organic farming en masse, it would be appropriate to carefully delineate areas or crops, where fertilizer use is nil or nominal, or demarcate export-oriented crops that can give a reasonable yield of high-quality produce without using chemicals. It is noteworthy that tuber crops hold great promise in this regard [24].

\section{Tuber crops: Underground crops with hidden treasures}

Tropical tuber crops, including cassava, yams (greater yam, white yam and lesser yam), sweet potato and aroids (EFY, taro and tannia), form the most important staple or subsidiary food for about 500 million global population [24]. Tuber crops are the third most important food crops for humans after cereals and grain legumes. These crops possess high photosynthetic ability, have the capacity to yield under poor and marginal soil conditions and can tolerate adverse weather conditions. They are also recognized as the most efficient in converting solar energy, cassava producing $250 \times 10^{3} \mathrm{kcal} \mathrm{ha}^{-1}$ and sweet potato $240 \times 10^{3} \mathrm{kcal} \mathrm{ha}^{-1}$, when compared with $176 \times 10^{3} \mathrm{kcal} \mathrm{ha}^{-1}$ for rice, $110 \times 10^{3} \mathrm{kcal} \mathrm{ha}^{-1}$ for wheat and $200 \times 10^{3} \mathrm{kcal} \mathrm{ha}^{-1}$ for maize; hence, the tropical root crops are known to be a cheap source of energy supply. They can serve as a substitute for cereals due to higher contents of carbohydrates and calories. The higher biological efficiency and the highest rate of dry matter production per unit area per unit time make tuber crops inevitable components of our food security systems. Besides, they have 
the potential to serve as sources of alcohol, starch, sago, liquid glucose, vitamin $C$ and raw materials for many other industrial products and animal feed. At times of famine, tuber crops have come in handy to overcome catastrophes and provide relief from hunger [24].

Tuber crops are cultivated in India mainly as rain-fed crops in the southern, eastern and northeastern states. These crops are the source of livelihood to small and marginal farmers and tribal population in these areas. Cassava production is mainly reported in the states of Kerala, Tamil Nadu, Andhra Pradesh and NEH regions. Sweet potato is cultivated mainly in the states of Orissa, Bihar, Jharkhand, eastern Uttar Pradesh, West Bengal, Madhya Pradesh, Maharashtra and Karnataka. Other tuber crops like yams (greater yam, white yam and lesser yam) and aroids (EFY, taro and tannia), popular as vegetables, are not yet commercially cultivated, being confined only to the home gardens in almost all the states (except EFY, which is cultivated on a commercial scale in Andhra Pradesh) [24].

\section{Prospects of organic farming in tropical tuber crops}

Organic farming is a viable strategy targeting on sustainable production and soil, environmental and human health hand in hand. Conventional agriculture using chemical inputs results in higher yield, but it is ecologically unfriendly as it has negative impacts on food, soil, water and environmental quality. Indiscriminate use of chemical fertilizers for decades has lowered the organic carbon status of our soils to $<1 \%$. Moreover, pesticide residues cause concern over the safety of food. In traditional agriculture, though the use of chemicals (fertilizers and pesticides) is not in practice, adequate care is not often taken for the maintenance of soil health and fertility [24].

Most of the tuber crops are grown by small and marginal farmers in rain-fed areas and tribal pockets and hence the use of chemical fertilizers and insecticides is limited except in the case of cassava in the industrial production areas of Tamil Nadu (Salem, Dharmapuri, Namakkal, and South Arcot districts) and Andhra Pradesh (Rajahmundry district). Tuber crops in general and aroids in particular, like EFY, do respond well to organic manures and there is considerable scope for organic production in these crops. Further, the tropical tuber crops are well adapted to low-input agriculture. They are less prone to pest and disease infestations. Research work done in India and elsewhere had shown that the use of chemical fertilizers are beneficial in maximizing production of these groups of crops. A perusal of data in Table 1 indicates the organic production potential of tropical tubers and experimental evidences clearly indicate that productivity can be achieved satisfactorily even in the absence of chemical fertilizers through proper supplementation of nutrients using organic sources. Moreover, at present, there is a great demand for organically produced vegetables, particularly aroids and yams, among affluent Asians and Africans living in developed nations (Europe, USA and Middle East). The export of these tuberous vegetables will gain impetus through special government programmes like the Agri Export Zone (AEZ) Programme in Kerala [24]. 


\begin{tabular}{|c|c|c|c|c|c|c|}
\hline \multirow[t]{2}{*}{ Tuber crop } & \multicolumn{2}{|c|}{$\begin{array}{l}\text { Tuber yield obtained due to } \\
\text { application of organic } \\
\text { manure (OM) alone }\end{array}$} & \multicolumn{3}{|c|}{ Tuber yield under OM + NPK } & \multirow[t]{2}{*}{ Reference } \\
\hline & OM used & $\begin{array}{l}\text { Tuber yield } \\
\left(\mathrm{t} \mathrm{ha} \mathrm{a}^{-1}\right)\end{array}$ & $\mathrm{OM}+\mathrm{NPK}$ & $\begin{array}{l}\text { Tuber yield } \\
\left(\mathrm{t} \mathrm{ha}^{-1}\right)\end{array}$ & $\begin{array}{l}\% \text { increase or decrease } \\
\text { over OM alone }\end{array}$ & \\
\hline \multirow[t]{3}{*}{ Cassava } & FYM & 10.45 & FYM + NPK & 28.17 & +169.57 & [26] \\
\hline & Ash & 12.25 & FYM + NPK & 28.17 & +129.95 & [26] \\
\hline & Ash + FYM & 13.29 & FYM + NPK & 28.17 & +111.96 & [26] \\
\hline Sweet potato & FYM & 15.57 & FYM + NPK & 18.88 & +21.25 & [27] \\
\hline \multirow{3}{*}{$\begin{array}{l}\text { White yam } \\
\text { (intercrop in } \\
\text { coconut) }\end{array}$} & FYM & 7.55 & FYM + NPK & 14.96 & +98.15 & [28] \\
\hline & $\begin{array}{l}\text { Coir pith } \\
\text { compost }\end{array}$ & 9.03 & $\begin{array}{l}\text { Coir pith } \\
\text { compost }+ \\
\text { NPK }\end{array}$ & 24.61 & +172.53 & [28] \\
\hline & $\begin{array}{l}\text { Green } \\
\text { manuring } \\
\text { with sunhemp }\end{array}$ & 7.16 & $\begin{array}{l}\text { Green } \\
\text { manure + } \\
\text { NPK }\end{array}$ & 16.06 & +124.30 & [28] \\
\hline
\end{tabular}

Source: Reference [29]

Table 1. Organic production potential of tropical tuber crops

\section{Issues in organic tuber production}

Practical applications and operational methodologies in organic farming, especially in tuber crops, are not available due to lack of comprehensive research in this field. Absence of package of practices recommendations for organic farming of tuber crops hinders the implementation and promotion of this sustainable alternative production system. Many methods and techniques of organic agriculture have originated from various traditional farming systems all over the world, where there is the non-use of chemical inputs. To the maximum extent possible, organic production systems rely on crop rotations, crop residues, animal manures, legumes, green manures, farm wastes, mineral-bearing rocks and aspects of biological pest control to maintain soil productivity, supply plant nutrients and control pests, diseases and weeds. Being highly responsive to organic manures and having fewer pests and disease problems when compared with cereals and vegetables, the main issue in organic production of tuber crops is the proper scientific use of a wide variety of cheaper and easily available organic sources of plant nutrients [24].

\section{Strategies for organic tuber production}

Building up of soil fertility of the land: Before the establishment of an organic management system, the fertility status of the land must be improved by growing green manure crops like cowpea twice or thrice in a year and incorporation of the green leaf matter at the appropriate pre-flowering stage. This will help re-establish the balance of the eco-system and offset the 
yield decline, if any, during the initial period of organic conversion, as tuber crops are highly nutrient-depleting crops. Virgin land or barren land, if available, will also be highly suitable for organic farming of tubers [24].

Use of planting materials produced by organic management: Varieties cultivated should be adapted to the soil and climatic conditions and as far as possible resistant to pests and diseases. Local market preference should also be taken into account. The planting materials should be produced by adopting organic management practices [24].

Meeting nutrient needs in organic tuber production: The potential organic sources of plant nutrients for tropical tuber crops are farmyard manure (FYM), poultry manure, composts like vermicompost, coir pith compost, mushroom spent compost, saw dust compost, press mud compost, green manures, crop residues, ash, oil cakes like neem cake, etc. Table 2 indicates the average nutrient contents in these organic sources [24].

Vermicompost, produced by chemical disintegration of organic matter by earthworms, is an ideal blend of plant nutrients with the worm enzyme and probiotics to boost the crop performance. It contains higher amount of nutrients, hormones and enzymes and has stimulatory effect on plant growth. If farmers can produce vermicompost utilizing on-farm wastes, organic farming of tuber crops becomes profitable [24].

Coir pith, an organic waste obtained as a by-product during the process of separation of fibre from coconut husk in the coir industry, is normally resistant to bio-degradation due to its high content of lignin, accumulating as an environmental pollutant. Extraction of $1 \mathrm{~kg}$ of coconut fibre generates $2 \mathrm{~kg}$ of coir pith, and in India, an estimated 5,00,000 MT of coir pith is produced per annum. The Coir Board in collaboration with TNAU has developed the technology for converting coir pith into organic manure using PITHPLUS, a spawn of edible mushroom, Pleurotus sajor caju. Coir pith compost developed from coir waste is a good form of organic manure and a soil conditioner and can be applied to tuber crops [24].

\begin{tabular}{llll}
\hline Organic manures & $\mathbf{N}(\%)$ & $\mathbf{P}_{2} \mathbf{O}_{5}(\%)$ & $\mathbf{K}_{2} \mathbf{O}(\%)$ \\
\hline Farmyard manure & 0.50 & 0.20 & 0.40 \\
\hline Poultry manure & $1.20-1.50$ & $1.40-1.80$ & $0.80-0.90$ \\
\hline Vermicompost & 1.50 & 0.40 & 1.80 \\
\hline Coir pith compost & 1.36 & 0.06 & 1.10 \\
\hline Press mud compost & 1.30 & 2.20 & 0.50 \\
\hline Mushroom spent compost & 1.84 & 0.69 & 1.19 \\
\hline Sawdust compost & 1.00 & 0.50 & 0.50 \\
\hline Biogas slurry & 1.41 & 0.92 & 0.84 \\
\hline Neem cake & 5.00 & 1.00 & 1.50 \\
\hline Bone meal & 3.50 & 21.00 & - \\
\hline Municipal compost & 1.20 & 0.04 & 0.90 \\
\hline
\end{tabular}

Source: Reference [24]

Table 2. Average nutrient contents of some organic manures 
The practice of green manuring for improving soil fertility and supplying a part of $\mathrm{N}$ requirement of crops is age old. Approximately $15-20 \mathrm{t} \mathrm{ha}^{-1}$ of green matter can be obtained from green manure crops like cowpea when grown in systems involving tuber crops. Nitrogen contribution by green manure crops varies from 60 to $280 \mathrm{~kg} \mathrm{ha}^{-1}$ [24].

Biofertilizers offer a cheap and easily available source of nutrients, especially $\mathrm{N}$ and $\mathrm{P}$, besides enhancing the efficiency of native and applied nutrients in the soil. The commonly used $\mathrm{N}$ biofertilizer for tuber crops is the $\mathrm{N}$-fixing bacterium, Azospirillum lipoferum, which can partially meet the $\mathrm{N}$ demand of the crop. Powdered neem cakes also serve as an organic $\mathrm{N}$ source. These organic $\mathrm{N}$ supplements unlike the fertilizer $\mathrm{N}$ do not suffer much loss in the fields and enhances the $\mathrm{N}$ recovery. Phosphorus-solubilizing and phosphorus-mobilizing organisms such as phosphobacterium and mycorrhizae are helpful in augmenting $\mathrm{P}$ availability of the soil [24].

Besides, natural reserves of rock phosphate are permitted for use as P fertilizer. Potassium for these crops can be supplied using K-rich organic amendments such as wood ash, rice straw and composted coir pith. K mobilizers can also be used for enhancing the K availability and meeting the K requirements. Harnessing the above-mentioned easily available organic sources of plant nutrients conjointly and judiciously to meet the nutrient needs of highly nutrientexhausting crops like tropical tubers will definitely help maintain/promote productivity in organic farming in the absence of chemical inputs [24].

Pest, disease and weed management: When compared with cereals and vegetables, tuber crops have fewer pest and disease problems. Barring a few major ones, like cassava mosaic disease (CMD), cassava tuber rot, sweet potato weevil (SPW), Phytophthora leaf blight in taro, and collar rot in EFY, the others are of minor significance. In general, for the management of pests and diseases, non-chemical measures or preventive cultural techniques can be resorted to. This includes use of tolerant/resistant varieties, use of healthy and disease-free planting materials, strict field sanitation (against almost all), deep ploughing (e.g. tuber rot), roguing the field (e.g. CMD), use of pheromone traps (e.g. SPW), use of trap crops (e.g. SPW, root knot nematodes), adapted crop rotations, use of neem cake (collar rot, tuber rot), use of bio-control agents like Trichoderma, Pseudomonas (collar rot, leaf blight), etc. [24].

Normally, two hand weedings are advocated in tuber crops for efficient weed management. As most of the tuber crops (except sweet potato) take approximately 75-90 days for sufficient canopy coverage, raising a short-duration intercrop (like green manure/vegetable/grain cowpea, vegetables, groundnut, etc., in cassava, cowpea in yams and aroids) can also help to a great extent to reduce weed problem. Mulching the crop using any locally available plant materials (green leaves, dried leaves, etc.) immediately after planting (in yams and aroids) will help conserve moisture and regulate temperature, apart from weed control [24].

\section{A decade of research on organic farming of tropical tuber crops}

The following research programmes were taken up at ICAR-Central Tuber Crops Research Institute, Sreekariyam, Thiruvananthapuram, Kerala, India, during 2004-2015: 
- Organic farming of EFY

- Varietal response to organic farming in EFY

- Validation and popularization of organic farming technology in EFY

- Organic farming of yams

- Organic farming of taro

- On-farm validation of organic farming of yams and taro

The major objectives were:

- To develop appropriate technologies for organic production of EFY, yams and taro, which would be safe and of good quality

- To assess the impact of organic farming in these crops on productivity, tuber quality, soil health and economics

\subsection{Methodology}

\subsubsection{Study site, experimental design, treatments and test variety}

Six separate field experiments were conducted at ICAR-Central Tuber Crops Research Institute, Thiruvananthapuram, India, over a decade (2004-2015) to compare organic management over conventional system in EFY, yams and taro in an acid Ultisol (pH: 4.3-5.0). The site experiences a typical humid tropical climate. The mean annual rainfall was 1,985 mm, maximum and minimum temperatures were $31.35^{\circ} \mathrm{C}$ and $24.50^{\circ} \mathrm{C}$, respectively, and relative humidity was $76.65 \%$. In general, for all the sites, prior to experimentation, the fertility status of the soil was found to be medium to high for organic C $(0.75-1.03 \%)$, low for available $\mathrm{N}$ (159-255 kg ha-1) and high for available P (142-217 kg ha ${ }^{-1}$ ) and available K (337-528 kg ha $\left.{ }^{-1}\right)$.

The impact of conventional, traditional, organic and biofertilizer production systems was evaluated in randomized block design (RBD) in EFY (var. Peerumade local) with five replications. Comparative response of five varieties of EFY (Gajendra, Sree Padma, Sree Athira and two locals) under organic and conventional farming was also evaluated in split plot design. The gross plot size was $4.5 \mathrm{~m} \times 4.5 \mathrm{~m}$ (25 plants) accommodating nine net plants. All the three trailing genotypes of edible Dioscorea (white yam: D. rotundata (var. Sree Priya), greater yam: D. alata (var. Sree Keerthi) and lesser yam: D. esculenta (var. Sree Latha)) were evaluated under conventional, traditional and organic farming systems in split plot design. The gross plot size was $7.2 \mathrm{~m} \times 3.6 \mathrm{~m}$ (32 plants of white yam and greater yam and 36 plants of lesser yam) accommodating 12 net plants of white yam and greater yam and 14 plants of lesser yam. The dwarf genotype of white yam (var. Sree Dhanya) was also evaluated under conventional, traditional, organic and integrated systems in RBD with five replications. Similarly, the response of three varieties of taro (Sree Kiran, Sree Rashmi and local) to conventional, traditional and organic farming systems was studied in split plot design. In split plot design, varieties/species were assigned to main plots and production systems to sub-plots and replicated thrice. Details of production systems are given in Table 3. 
The on-station organic production technology developed for EFY was validated through onfarm trials (OFT) conducted at 10 sites covering 5 ha in Kerala under the project financed by the National Horticulture Mission. In yams and taro, the technologies were confirmed through OFT conducted at seven sites.

Chemical inputs were not used for a year prior to the start of the investigations. In "conventional plots", FYM + nitrogen, phosphorus, potassium (NPK) fertilizers were applied. Farmers' practice of using FYM and ash was followed in "traditional plots". In "organic farming plots", FYM, green manure, ash, neem cake and/or biofertilizers were applied to substitute chemical fertilizers. In "biofertilizer farming", FYM, mycorrhiza, Azospirillum and phosphobacterium were applied. In "integrated farming", FYM, chemical fertilizers and biofertilizers were used. Organically produced planting materials were used for the study.

\begin{tabular}{|c|c|c|c|c|}
\hline \multirow[t]{2}{*}{ Crop } & \multicolumn{4}{|c|}{ Description of production systems } \\
\hline & Conventional & Traditional & Organic & Biofertilizers/integrated \\
\hline EFY & $\begin{array}{l}\text { FYM @ } 25 \mathrm{t} \mathrm{ha}^{-1}+ \\
\text { NPK } @ 100: 50: \\
150 \text { kg ha- }\end{array}$ & $\begin{array}{l}\text { FYM@36 tha-1 }+ \\
\text { ash @ } 3 \mathrm{tha}^{-1}\end{array}$ & $\begin{array}{l}\text { Seed treatment in FYM + neem cake } \\
+ \text { Trichoderma harzianum slurry. } \\
\text { Application of FYM @ } 36 \mathrm{t} \mathrm{ha}^{-1} \\
\text { (FYM: neem cake mixture }(10: 1 \\
\text { ratio) incubated with Trichoderma } \\
\text { harzianum) + in situ green manuring } 1 \\
\text { with cowpea (green matter @ } 20-25 \mathrm{t} \\
\left.\mathrm{ha}^{-1}\right)+ \text { neem cake @ } 1 \mathrm{tha}^{-1}+\text { ash @ } 3 \\
\mathrm{t} \mathrm{ha}^{-1}\end{array}$ & $\begin{array}{l}\text { Biofertilizers } \\
\text { FYM@ } 25 \text { t ha }^{-1} \\
\text { mycorrhiza @ } 5 \mathrm{~kg} \mathrm{ha}^{-1} \\
\text { Azospirillum @ } 3 \mathrm{~kg} \mathrm{ha}^{-1} \\
\text { and phosphobacteria @ } 2.5 \\
\mathrm{~kg} \mathrm{ha}^{-1} \\
\mathrm{t}\end{array}$ \\
\hline Yams & $\begin{array}{l}\text { FYM@ } 10 \text { t ha }^{-1}+ \\
\text { NPK@ } 90: 60: 80 \text { kg } \\
\text { ha }^{-1}\end{array}$ & $\begin{array}{l}\text { FYM@ } 15 \mathrm{t} \mathrm{ha}^{-1}+ \\
\text { ash } @ 1.5 \mathrm{t} \mathrm{ha}^{-1}\end{array}$ & $\begin{array}{l}\text { FYM@ } 15 \mathrm{t} \mathrm{ha}^{-1}+\text { in situ green } \\
\text { manuring with cowpea (green } \\
\left.\text { matter@15-20 tha }{ }^{-1}\right)+ \text { neem cake @ } \\
1 \text { tha }{ }^{-1}+\text { ash @ } 1.5 \mathrm{tha}^{-1}+ \\
\text { biofertilizers }(\text { Azospirillum } @ 3 \mathrm{~kg} \text { ha } \\
{ }^{-1} \text { mycorrhiza } 95 \mathrm{~kg} \mathrm{ha}^{-1} \text { and } \\
\text { phosphobacteria@ } 3 \mathrm{~kg} \mathrm{ha}^{-1} \text { ) }\end{array}$ & \\
\hline $\begin{array}{l}\text { Dwarf white } \\
\text { yam }\end{array}$ & $\begin{array}{l}\text { FYM@10 t ha }{ }^{-1}+ \\
\text { NPK@ } 90: 60: 80 \text { kg } \\
\text { ha }^{-1}\end{array}$ & $\begin{array}{l}\text { FYM@15 t ha-1 }+ \\
\text { ash @ } 1.5 \mathrm{t} \mathrm{ha}^{-1}\end{array}$ & $\begin{array}{l}\text { FYM@ } 15 \mathrm{t} \mathrm{ha}^{-1}+\text { in situ green } \\
\text { manuring with cowpea (green } \\
\left.\text { matter@15-20 } \mathrm{t} \mathrm{ha}^{-1}\right)+ \text { neem cake } @ \\
1 \mathrm{tha}^{-1}+\text { ash } @ 1.5 \mathrm{tha}^{-1}+ \\
\text { biofertilizers }(\text { Azospirillum } @ 3 \mathrm{~kg} \text { ha } \\
\left.-1 \text { and mycorrhiza } 95 \mathrm{~kg} \mathrm{ha}^{-1}\right)\end{array}$ & $\begin{array}{l}\text { Integrated } \\
\text { FYM @ } 10 \mathrm{tha}^{-1}+\mathrm{NPK} @ \\
40: 30: 80 \mathrm{~kg} \mathrm{ha}^{-1}+ \\
\text { biofertilizers (Azospirillum } \\
@ 3 \mathrm{~kg} \mathrm{ha}^{-1} \text { and mycorrhiza } \\
@ 5 \mathrm{~kg} \mathrm{ha}^{-1} \text { ) }\end{array}$ \\
\hline Taro & $\begin{array}{l}\text { FYM @ } 12 \mathrm{t} \mathrm{ha}^{-1}+ \\
\text { NPK @ 80:25:100 kg } \\
\text { ha }^{-1}\end{array}$ & $\begin{array}{l}\text { FYM@ } 15 \mathrm{t} \mathrm{ha}^{-1}+ \\
\text { ash@ } 2.0 \mathrm{tha}^{-1}\end{array}$ & 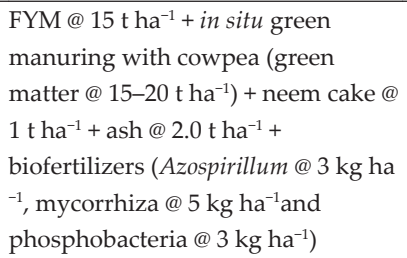 & \\
\hline
\end{tabular}

Table 3. Description of production systems in various organic farming experiments 


\subsubsection{Plant and soil measurements}

Pooled analysis of yield data was performed. Yield stability index was calculated using the following formula: stability index $=($ Avg $Y-S D) / Y \max$, where Avg $\mathrm{Y}=$ average yield over five years, $\mathrm{SD}=$ standard deviation, $\mathrm{Ymax}=$ maximum yield over the five years. A stability index value towards unity indicates greater stability. Proximate analyses of tubers for dry matter, starch, total sugars, reducing sugars, crude protein, oxalates and total phenols [30-33], mineral composition of corms, namely $\mathrm{P}, \mathrm{K}, \mathrm{Ca}, \mathrm{Mg}, \mathrm{Cu}, \mathrm{Zn}, \mathrm{Mn}$ and Fe contents [34], chemical parameters of soil, namely organic $\mathrm{C}$ (soil organic matter (SOM)), $\mathrm{pH}$, available $\mathrm{N}, \mathrm{P}, \mathrm{K}, \mathrm{Ca}$, $\mathrm{Mg}, \mathrm{Cu}, \mathrm{Zn}, \mathrm{Mn}$ and Fe status [35], physical characters of the soil such as bulk density, particle density, water-holding capacity (WHC) and porosity [36], plate count of soil microbes, namely bacteria, fungi, actinomycetes, $\mathrm{N}$ fixers and P solubilizers [37] and the activity of dehydrogenase enzyme [38], were determined by standard procedures. Economic analysis was performed; net income and benefit:cost ratio were computed. The soil quality index (SQI) was computed in EFY based on the method developed by Karlen and Stott [39]. The analysis of variance of data was performed using reference [40] by applying analysis of variance technique (ANOVA) for RBD and split plot design.

\subsubsection{Development of a learning system}

A learning system was developed using artificial neural networks (ANN) to predict the performance of EFY production system [41, 42]. A three-layered system with one input layer, one output layer and one hidden layer was developed. The input layer neurons included temperature, rainfall, planting material, FYM, potassium, phosphorus, ash, neem cake, Azospirillum, phosphobacteria, mycorrhiza and green manure. The output layer neurons were total biomass, corm yield, canopy spread and plant height.

\subsection{Implications}

\subsubsection{Varietal response to organic management}

Pooled analysis indicated that the elite and local varieties of EFY and taro and all the three species of Dioscorea were on a par under both the systems (Figure 1). However, the Gajendra variety of EFY and all the species of Dioscorea yielded more under organic farming than conventional practice (Figure 1). In taro, all the varieties produced slightly higher yield under chemical farming.

\subsubsection{Yield and economics}

Organic farming resulted in 10-20\% higher yield in EFY, white yam, greater yam, lesser yam and dwarf white yam, i.e., 20, 9, 11, 7 and 9\%, respectively (Table 4). This is contrary to some of the reports that crop yields under organic management are $20-40 \%$ lower than those under comparable conventional systems [43, 44]. Taro preferred chemical-based farming as a slight reduction in the crop yield was noticed under organic farming (5\%). 


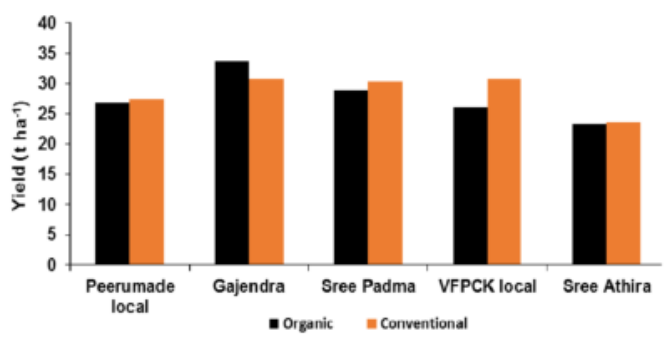

EFY

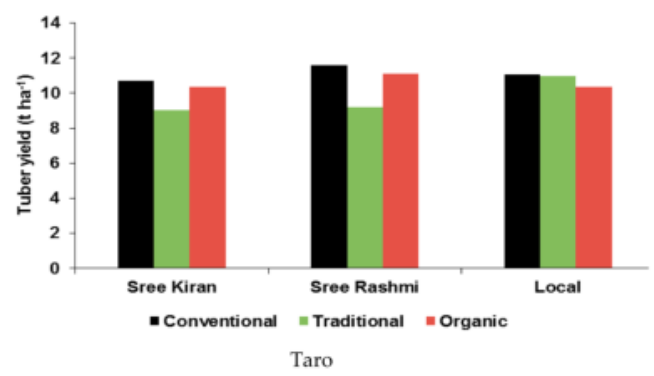

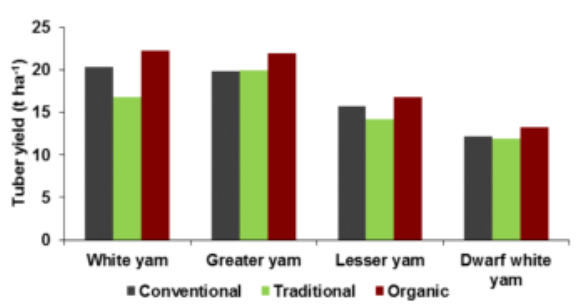

Yams

Figure 1. Varietal response to organic farming in tuber crops

It has been reported that yields were directly related to the intensity of farming in the prevailing conventional system $[45,46]$. This means that in areas of intensive farming system, shifting to organic agriculture decreases the yield depending on the intensity of external input use before conversion [48, 49]. As EFY and yams are traditionally grown with low external inputs using organic wastes and manures available in the homesteads, organic management in the present study has shown a potential to increase yields over conventional practice. The higher yield may be due to the overall improvement in the physico-chemical and biological properties of soil under the influence of organic manures $[9,50,51]$.

\begin{tabular}{llll}
\hline Tuber crop & Conventional & Organic & \% increase/decrease \\
\hline EFY & 47.61 & 57.10 & 19.93 \\
\hline White yam & 20.31 & 22.21 & 9.35 \\
\hline Greater yam & 19.87 & 21.96 & 10.51 \\
\hline Lesser yam & 15.75 & 16.83 & 6.85 \\
\hline Dwarf white yam & 13.23 & 12.18 & 8.62 \\
\hline Taro & 11.12 & 10.61 & -4.58 \\
\hline
\end{tabular}

Source: Reference [47]

Table 4. Yield $\left(\mathrm{t} \mathrm{ha}^{-1}\right)$ under organic vs conventional management in tuber crops (pooled mean) 
Tropical tuber crops, like EFY and yams, are nutrient-exhausting crops. In general, the nutrient removal by these crops yielding 17-33 tonnes of tuber was $112-180 \mathrm{~kg} \mathrm{~N}, 15-24 \mathrm{~kg}$ P and 93$239 \mathrm{~kg} \mathrm{~K}$ per ha [52]. The potential yield of these crops can be obtained by proper renewal of soil with adequate amounts of nutrients. These results highlight that in the absence of chemical fertilizers, in organic agriculture, a higher yield can be obtained through proper addition of nutrients based on soil testing by way of cheaper and easily available, on-farm-generated organic sources [3].

The long-term performance of organic vs conventional management in aroids and yams was analysed through the stability index calculated over a five-year period, and it was found that organic farming was equally stable as that of conventional practice (Figure 2).

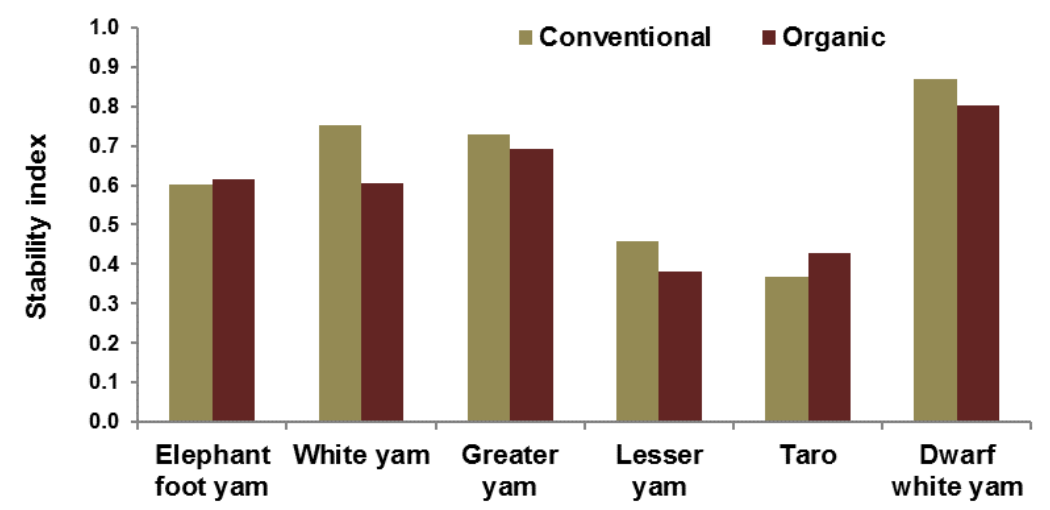

Figure 2. Yield stability index in organic vs conventional management in aroids and yams

The view of field experimentation in EFY is given in Figure 3. Yield trend over five years and pooled analysis indicated the significantly superior performance of organic farming in EFY (Figure 4; Table 5). Cost-benefit analysis in EFY indicated that the net profit was 28\% higher and an additional income of Rs. 47,716 ha-1 was obtained due to organic farming, which was obviously due to $20 \%$ higher yield [12] (Table 5).

In yams, up to third year, organic farming proved to be superior; thereafter, it was on a par and slightly lower than conventional practice. Pooled analysis in yams indicated that organic farming was significantly superior to conventional practice and produced $9.12 \%$ higher yield (Figure 5; Table 6). Species $\times$ production systems interaction was absent. However, in all the species, organic farming produced slightly higher yield than conventional practice. Dwarf white yam also responded similarly to both the systems with slightly higher yield under organic practice (Figures 6 and 7).

In taro, yield trend over five years (except during the first year, when organic farming was superior to conventional practice) and pooled mean indicated that organic farming was on a 
par with conventional practice, but chemical farming produced a slightly higher yield (Table 4; Figures 8 and 9). This was because taro leaf blight could not be controlled by organic measures.

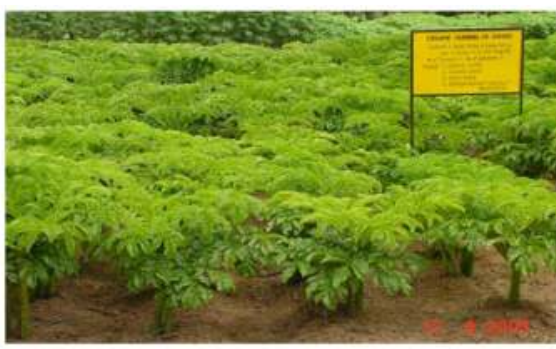

Field view of organic farming of EFY

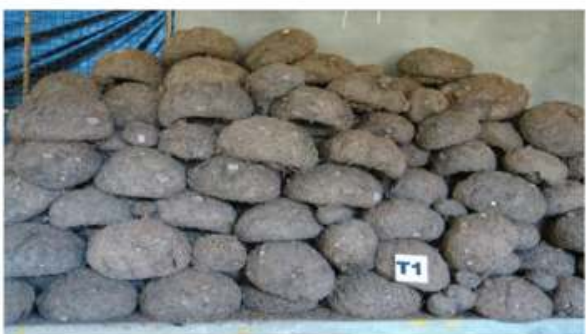

Conventional corms

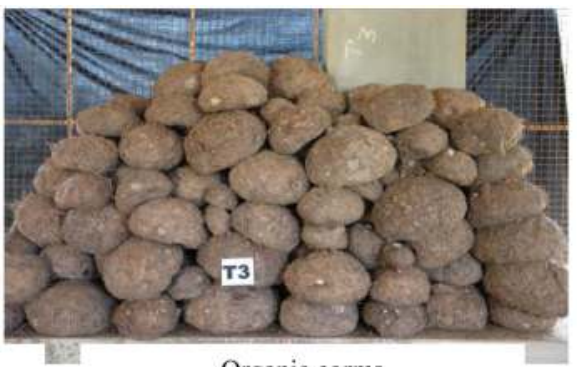

Organic corms

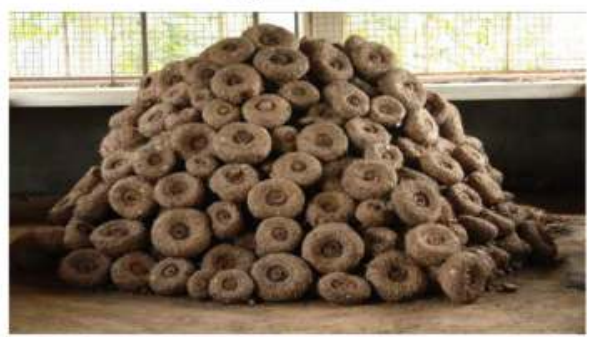

Bumper yield of organic corms

Figure 3. View of field experimentation in EFY

\begin{tabular}{|c|c|c|c|c|c|c|}
\hline $\begin{array}{l}\text { Production } \\
\text { systems }\end{array}$ & $\begin{array}{l}\text { Mean corm } \\
\text { weight } \\
\left(\mathrm{kg} \mathrm{plant}^{-1}\right)\end{array}$ & $\begin{array}{l}\text { Corm yield } \\
\left(\mathrm{t} \mathrm{ha} \mathrm{a}^{-1}\right)\end{array}$ & $\begin{array}{l}\text { Gross income } \\
(\text { Rs. ha-1) }\end{array}$ & $\begin{array}{l}\text { Gross costs } \\
\left(\text { Rs. ha }{ }^{-1}\right)\end{array}$ & $\begin{array}{l}\text { Net income } \\
\left(\text { Rs. ha }{ }^{-1}\right)\end{array}$ & B:C ratio \\
\hline & \multicolumn{6}{|c|}{ (Pooled mean of 5 years) } \\
\hline Conventional & 3.91 & 47.61 & $3,80,872$ & $2,12,812$ & $1,68,060$ & 1.79 \\
\hline Traditional & 3.69 & 44.96 & $3,59,680$ & $2,18,800$ & $1,40,880$ & 1.64 \\
\hline Organic & 4.69 & 57.10 & $4,56,776$ & $2,41,000$ & $2,15,776$ & 1.90 \\
\hline Biofertilizers & 3.45 & 42.07 & $3,36,528$ & $2,16,240$ & $1,20,288$ & 1.56 \\
\hline CD (0.05) & 0.292 & 3.550 & & & & \\
\hline
\end{tabular}

Source: Reference [12]

Table 5. Yield and economic advantage of organic farming over other production systems in EFY 


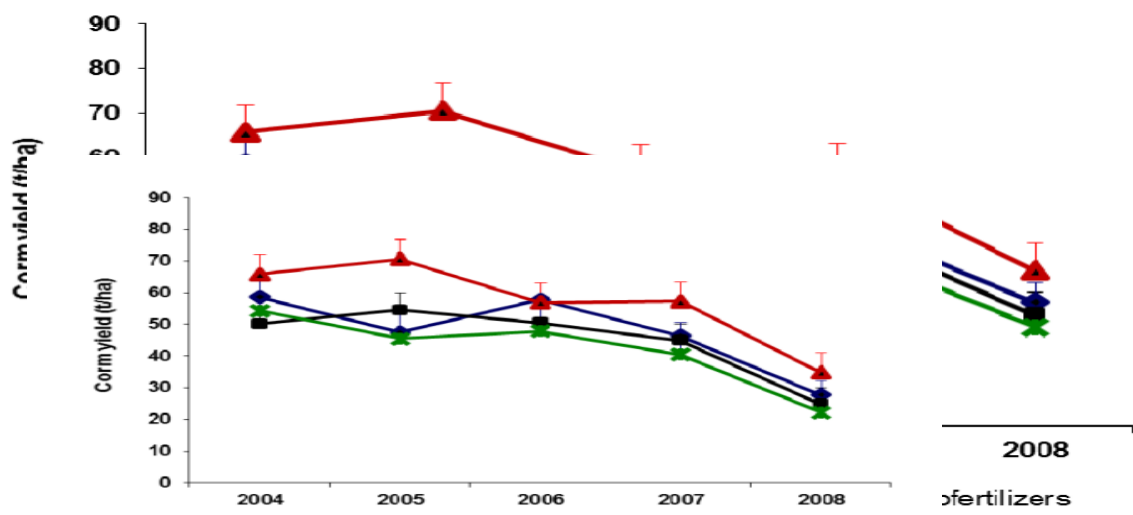

Figure 4. Yield trend over years as influenced by production systems in EFY
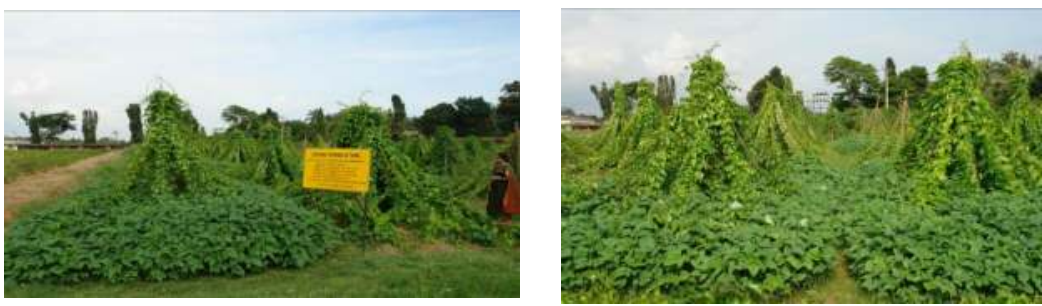

Field view of organic farming of yams: Green manuring, cost effective component

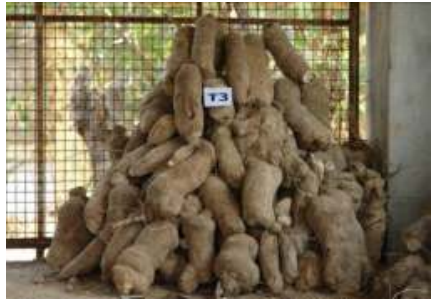

Organic white yam tubers

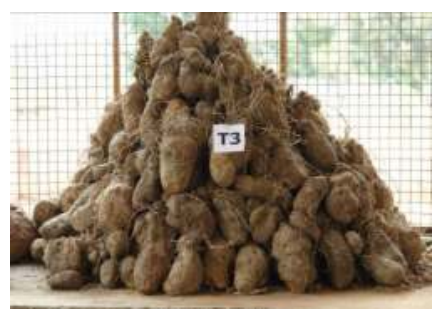

Organic greater yam tubers

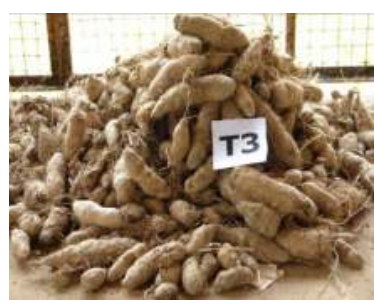

Organic lesser yam tubers

Figure 5. Field experimentation on organic farming of trailing genotypes of yams 


\begin{tabular}{lllll}
\hline Species/production systems & Conventional system & Traditional system & Organic system & $\begin{array}{l}\text { Mean of Dioscorea } \\
\text { species }\end{array}$ \\
\hline Dioscorea rotundata & 20.31 & 16.76 & 22.21 & 19.76 \\
\hline Dioscorea alata & 19.87 & 19.97 & 21.96 & 20.61 \\
\hline Dioscorea esculenta & 15.75 & 14.18 & 16.83 & 15.58 \\
\hline Mean of production systems & 18.64 & 16.97 & 20.34 & \\
\hline CD $(0.05)$ & Dioscorea species: $1.23 ;$ production systems: $1.23 ;$ species $\times$ systems: NS
\end{tabular}

Source: Reference [3]

Table 6. Yield response of Dioscorea species to production systems ( $\left.\mathrm{t} \mathrm{ha}^{-1}\right)$ (pooled mean)
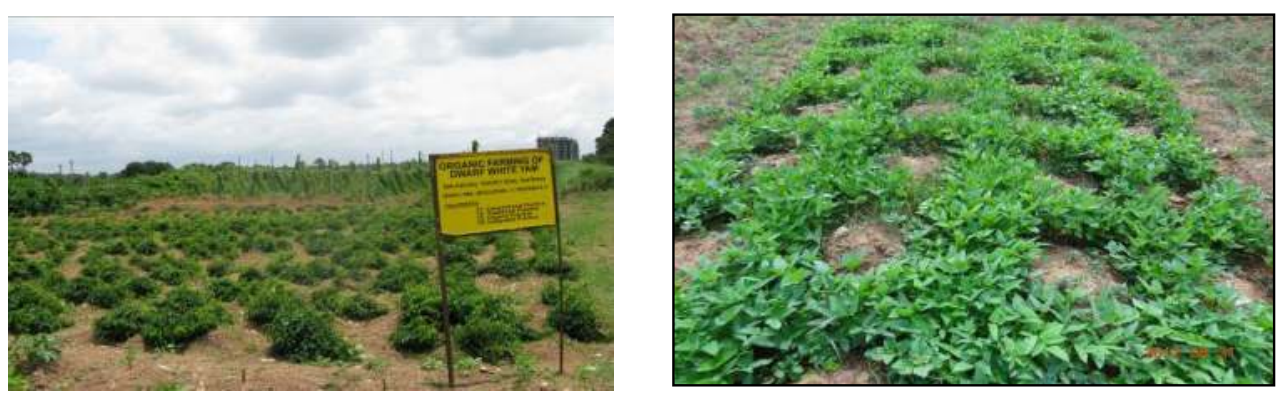

Field view of organic farming of dwarf white yam: Green manuring, cost effective component
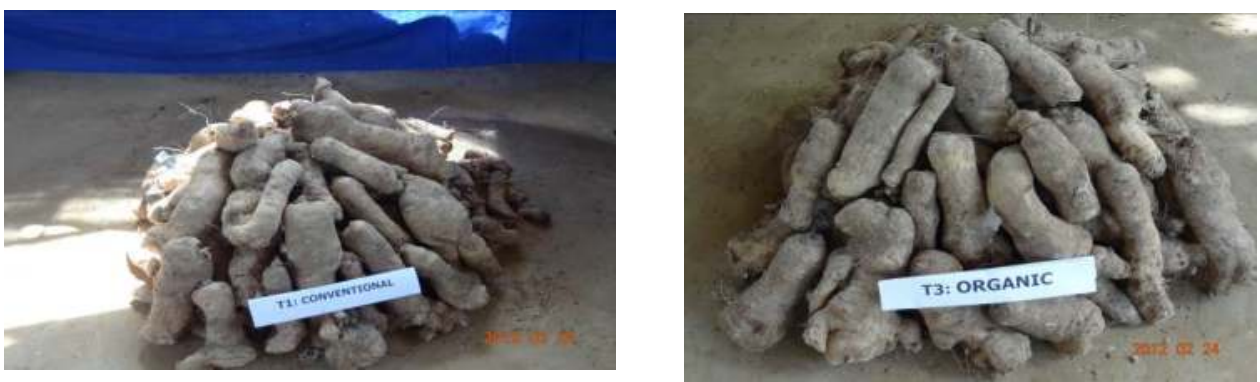

Figure 6. Field experimentation on organic dwarf white yam production 


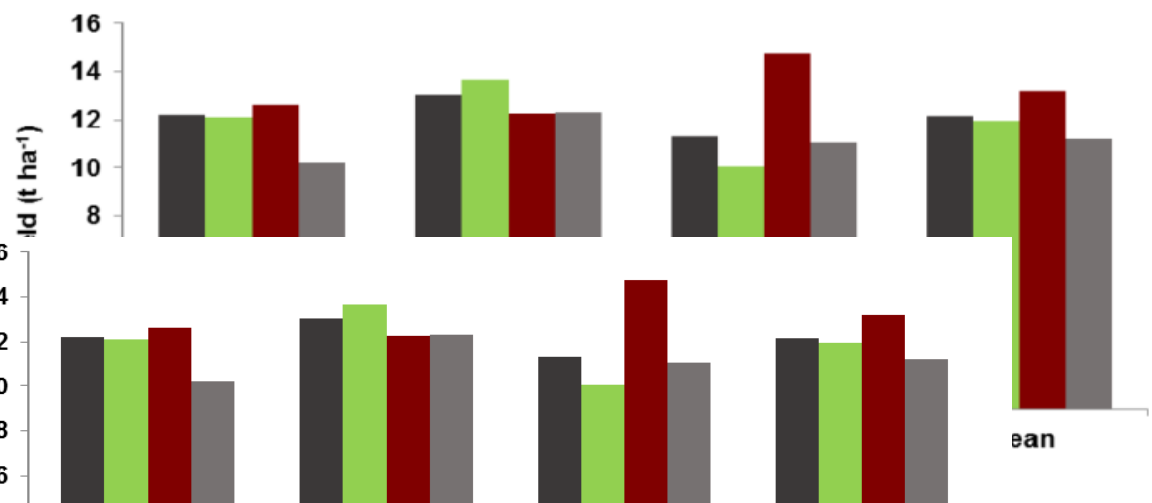

Figure 7. Yield trend over years as affected by production systems in dwarf white yam
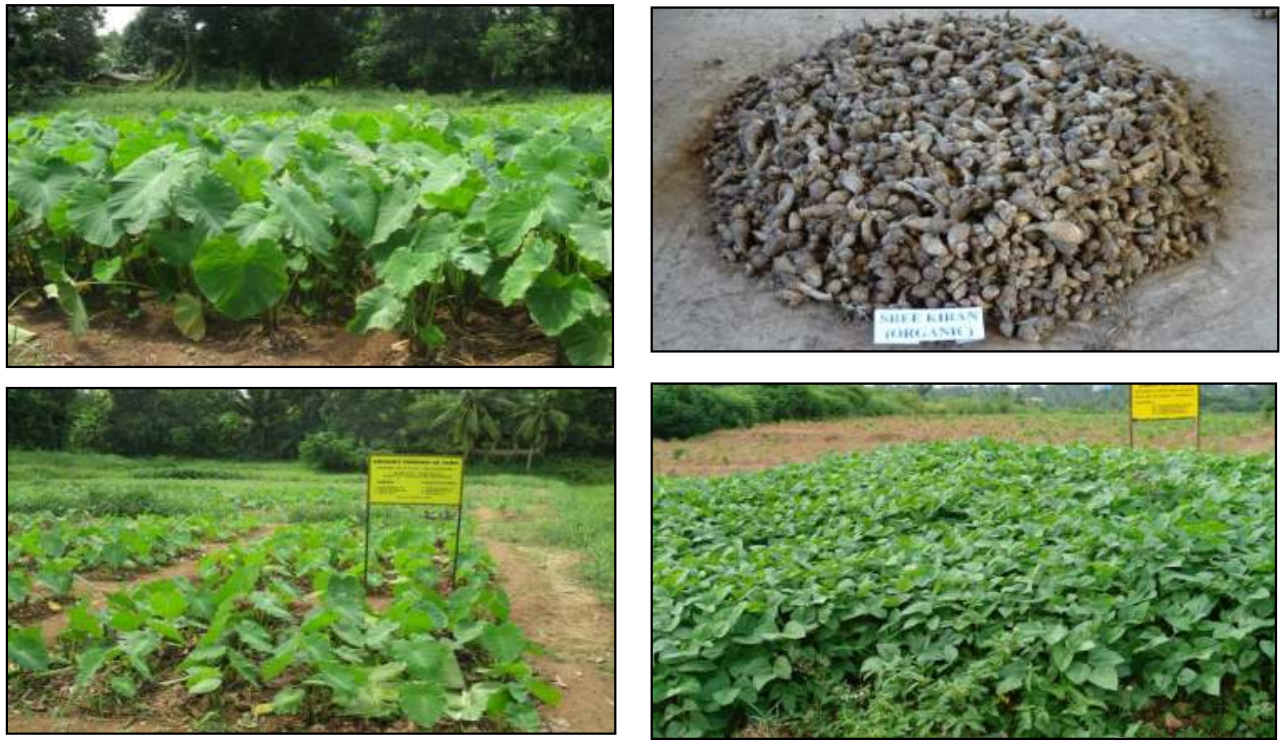

Figure 8. Field view of organic taro production with green manuring as the component 


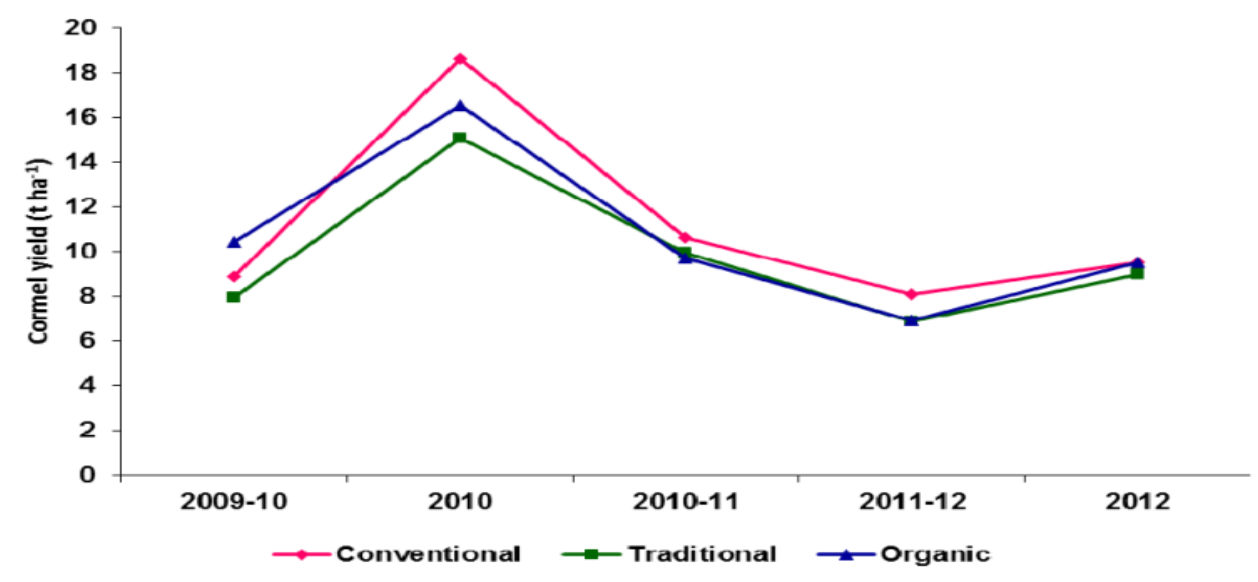

Figure 9. Yield trend as affected by production systems in taro

\subsubsection{Nutritional quality of tubers}

It is well known that plants absorb nutrients in the form of inorganic ions irrespective of whether the nutrient source is organic or inorganic. The absorbed nutrients are re-synthesized into compounds that determine the quality of the produce, which is largely decided by the genetic make-up of the plants $[5,12]$. However, in the present research, dry matter and starch contents of organically produced EFY corms were significantly higher (by 7 and 13\%), and crude protein (by 12\%), K, Ca and Mg (by 3-7\%) were slightly higher than those of conventional corms (Tables 7 and 8 and Figures 10 and 11). The anti-nutritional factor, oxalate, content in EFY was significantly lower (by 21\%) due to organic management. Total sugar and total phenol contents of conventional corms were significantly higher. In yams, the tuber quality was improved with significantly higher $\mathrm{Ca}$, slightly higher dry matter, crude protein (by 6-7\%), K and $\mathrm{Mg}$ contents. Synthetic fertilizers enhanced the total sugars, reducing sugars and total phenol contents slightly. The cooking quality of organically produced tubers did not differ from that of conventional tubers (Tables 7 and 8 and Figures 10 and 11).

Earlier reports indicate that organic crops contain more dry matter, minerals, especially $\mathrm{Fe}$, $\mathrm{Mg}$ and $\mathrm{P}$, by 21, 29 and $14 \%$ over conventionally produced ones [7]. As stated in references $[3,53]$, higher levels of $\mathrm{K}$ were found in organic tomatoes. There is a higher population of micro-organisms in organically managed soil. These micro-organisms produce many compounds that combine with soil minerals and make them more available to plant roots [54], which might have ultimately enhanced the mineral content of tubers. 


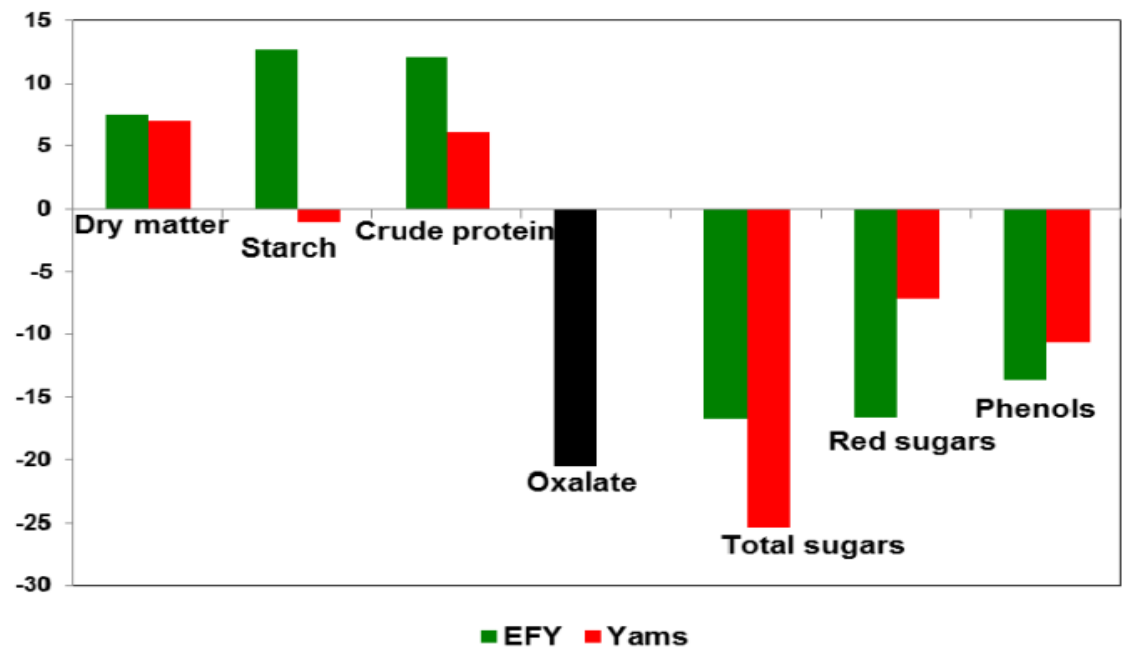

Figure 10. Per cent increase/decrease in biochemical parameters of organic tubers

\begin{tabular}{|c|c|c|c|c|c|c|}
\hline \multirow{2}{*}{$\begin{array}{l}\text { Biochemical } \\
\text { parameters }\end{array}$} & \multicolumn{3}{|c|}{ EFY } & \multicolumn{3}{|c|}{ Yams } \\
\hline & Organic & Conventional & CD (0.05) & Organic & Conventional & $\mathrm{CD}(0.05)$ \\
\hline Dry matter (\%) & 21.41 & 19.93 & 1.061 & 33.56 & 31.36 & NS \\
\hline $\begin{array}{l}\text { Starch } \\
\text { (\% FW basis) }\end{array}$ & 16.54 & 14.68 & 0.937 & 26.40 & 26.70 & NS \\
\hline $\begin{array}{l}\text { Crude protein } \\
\text { (\% FW basis) }\end{array}$ & 2.04 & 1.82 & NS & 2.04 & 1.92 & NS \\
\hline $\begin{array}{l}\text { Oxalate } \\
\text { (\% DW basis) }\end{array}$ & 0.186 & 0.234 & 0.0259 & & & \\
\hline $\begin{array}{l}\text { Total sugars } \\
\text { (\% FW basis) }\end{array}$ & 1.98 & 2.38 & 0.257 & 1.88 & 2.52 & NS \\
\hline $\begin{array}{l}\text { Reducing sugar } \\
\text { (\% FW basis) }\end{array}$ & 0.65 & 0.78 & NS & 0.12 & 0.13 & NS \\
\hline $\begin{array}{l}\text { Total phenols } \\
\left(\mathrm{mg} 100 \mathrm{~g}^{-1}\right)\end{array}$ & 69.70 & 80.80 & 8.28 & 37.20 & 61.60 & NS \\
\hline
\end{tabular}

Source: Reference [14]

Table 7. Comparison of biochemical constituents of organic vs conventional tubers 


\begin{tabular}{|c|c|c|c|c|c|c|}
\hline \multirow{2}{*}{ 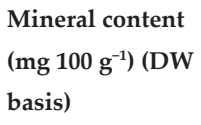 } & \multicolumn{3}{|c|}{ EFY } & \multicolumn{3}{|c|}{ Yams } \\
\hline & Organic & Conventional & $\mathrm{CD}(0.05)$ & Organic & Conventional & $\mathrm{CD}(0.05)$ \\
\hline $\mathrm{P}$ & 427.50 & 455.20 & NS & 411.80 & 472.40 & 39.79 \\
\hline K & 1813.00 & 1714,00 & 207.40 & $1,051.30$ & $1,026.70$ & NS \\
\hline $\mathrm{Ca}$ & 152.20 & 142.00 & 17.58 & 72.70 & 57.70 & 11.35 \\
\hline $\mathrm{Mg}$ & 276.50 & 268.10 & NS & 180.60 & 161.70 & NS \\
\hline $\mathrm{Cu}$ & 1.04 & 1.08 & NS & 0.24 & 0.29 & NS \\
\hline Zn & 11.02 & 11.62 & NS & 4.49 & 4.45 & NS \\
\hline $\mathrm{Mn}$ & 2.32 & 3.21 & 0.419 & 0.35 & 0.32 & NS \\
\hline $\mathrm{Fe}$ & 71.90 & 86.60 & NS & 5.03 & 5.13 & NS \\
\hline
\end{tabular}

Table 8. Comparison of mineral content of organic vs conventional tubers

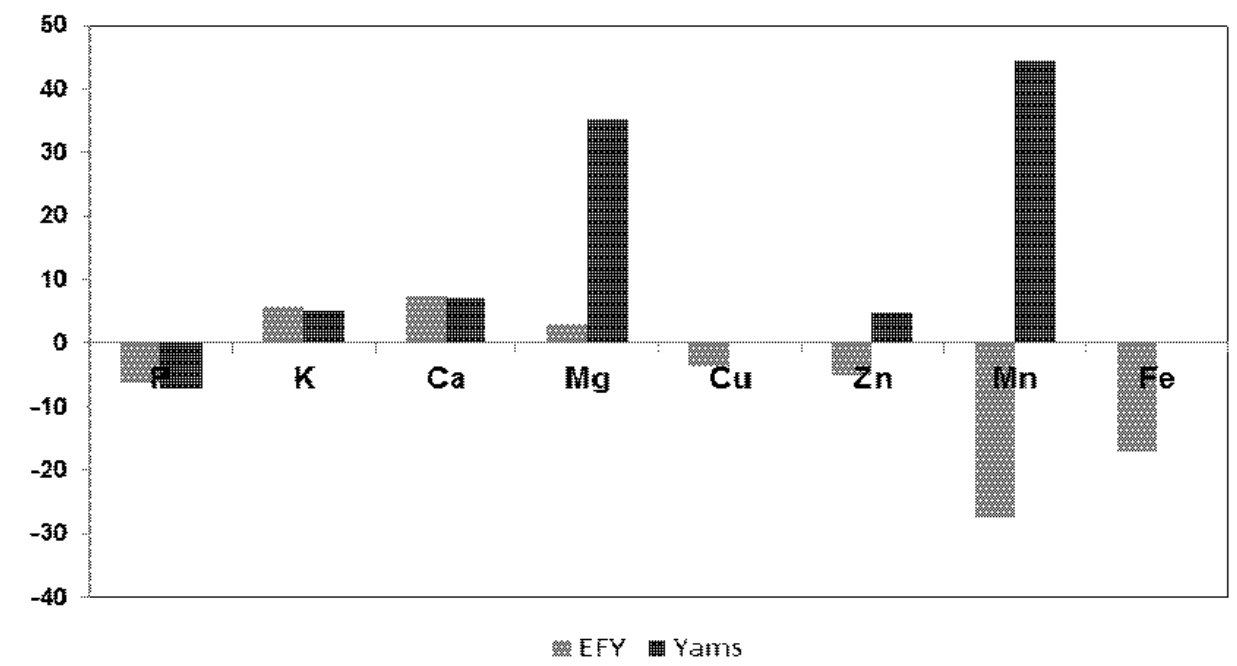

Figure 11. Per cent increase/decrease in mineral composition of organically produced tubers

Biochemical parameters of tubers were not significantly affected in taro and dwarf white yam. However, in taro, organic cormels had higher dry matter, starch and total sugars; conventional cormels had higher phenol, fibre and ash contents. Mineral content of cormels of taro also remained unaffected due to the production systems, though there was a slight increase in $\mathrm{P}$, $\mathrm{K}, \mathrm{Ca}$ and $\mathrm{Mg}$ contents in organic cormels (Figure 12). 


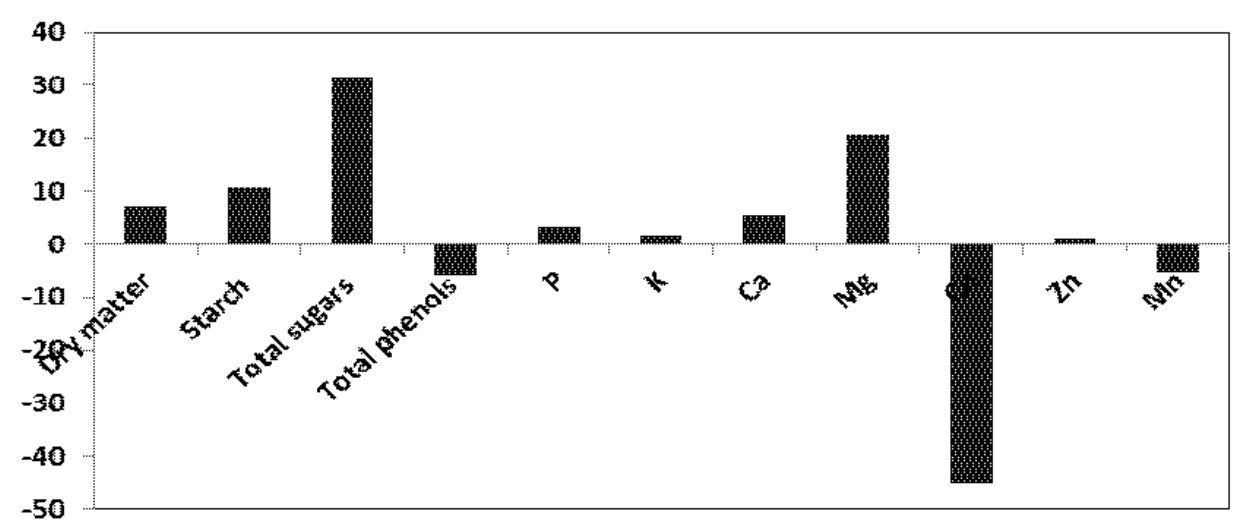

Figure 12. Per cent increase/decrease in biochemical and mineral composition in organic cormels of taro

\subsubsection{Soil quality}

\subsubsection{Physico-chemical-biological indicators}

The water-holding capacity was significantly higher under organic management $\left(14 \mathrm{~g} \mathrm{~cm}^{-3}\right)$ in EFY and yams over conventional practice (11-12 $\left.\mathrm{g} \mathrm{cm}^{-3}\right)$. It was 28, 15 and 19\% higher than that of conventional practice in EFY, yams and taro, respectively (Tables 9 and 10). Increased aeration, porosity and water-holding capacity of soils have been observed under organic management $[51,55,56]$. Moreover, changes in organic matter contribute to changes in soil biological and physical properties [9]. The higher organic $C$ and organic matter contents under organic management in these crops might have resulted in the formation of stable soil aggregates leading to a slight decrease in bulk density and increase in waterholding capacity [3].

There was significant improvement in $\mathrm{pH}$ in organic farming $(0.77,0.46,1.11$ and 1.20 unit increase over conventional system) in EFY, trailing yams, dwarf white yam and taro (Tables 11 and 12). Several earlier workers have reported that significant improvement in $\mathrm{pH}$ under organic management may be due to elimination of $\mathrm{NH}_{4}$ fertilizers, addition of cations especially via green manure applications, decrease in the activity of exchangeable $\mathrm{Al}^{13+}$ ions in soil solution due to chelation by organic molecules and self-liming effect of the Ca content in FYM $(0.14 \%)$ and ash (20-40\%) [3, 57-59].

The organic C content increased by $14-40 \%$ in organic plots over conventional plots in these crops (Tables 11 and 12). Higher organic $C$ status of organic plots might be attributed to considerable addition of organic manures particularly green manure cowpea. In EFY, exchangeable $\mathrm{Mg}$, available $\mathrm{Cu}, \mathrm{Mn}$ and Fe contents were significantly higher in organic plots (Figure 13). Organic plots showed significantly higher available K (by 34\%) in yams and 
available $\mathrm{P}$ in taro (Tables 11 and 12). Higher available $\mathrm{P}$ in organic plots may be due to solubilization of native $\mathrm{P}$ by organic acids during decomposition of organic manures and increased mineralization of $P$ from the added organic manures $[3,12]$. The higher content of available $\mathrm{K}$ in organic plots may be due to the higher content of $\mathrm{K}$ in the organic manures, especially green manure and ash (Table 2 ), greater mining of $K$ from the sub-surface layers by the extensive root system of green manure crop of cowpea, and dissolution of $\mathrm{K}$ from the inaccessible $\mathrm{K}$ minerals in the soil by organic acids during green manure decomposition $[3,12]$.

The soil $\mathrm{pH}$ is the most important determinant of soil nutrient availability. As reported in reference [59], the rise in soil $\mathrm{pH}$ to neutral range under organic management in these crops might have enhanced the availability of major, secondary and micro-nutrients to some extent. Moreover, organic manures used in the study, FYM, green manure cowpea and neem cake that contain major, secondary and micro-nutrients might also have contributed to this $[3,12]$.

\begin{tabular}{|c|c|c|c|c|c|c|c|c|}
\hline \multirow{2}{*}{$\begin{array}{l}\text { hysical } \\
\text { parameters }\end{array}$} & \multicolumn{4}{|c|}{ EFY } & \multicolumn{4}{|c|}{ Yams } \\
\hline & Organic & Conventional & $\begin{array}{l}\mathrm{CD} \\
(0.05)\end{array}$ & $\begin{array}{l}\% \text { increase } \\
\text { or } \\
\text { decrease }\end{array}$ & Organic & Conventional & $\begin{array}{l}\text { CD } \\
(0.05)\end{array}$ & $\begin{array}{l}\% \\
\text { increase } \\
\text { or } \\
\text { decrease }\end{array}$ \\
\hline $\begin{array}{l}\text { Bulk density } \\
\left(\mathrm{g} \mathrm{cm}^{-3}\right)\end{array}$ & 1.54 & 1.58 & NS & -2.29 & 1.61 & 1.63 & NS & -1.23 \\
\hline $\begin{array}{l}\text { Particle density } \\
\left(\mathrm{g} \mathrm{cm}^{-3}\right)\end{array}$ & 2.29 & 2.30 & NS & -0.61 & 2.27 & 2.40 & NS & -5.42 \\
\hline $\begin{array}{l}\text { Water-holding } \\
\text { capacity (\%) }\end{array}$ & 14.11 & 10.99 & 2.442 & +28.38 & 14.21 & 12.38 & 1.604 & +14.78 \\
\hline Porosity (\%) & 36.51 & 31.35 & NS & +16.45 & 31.30 & 32.07 & NS & -2.40 \\
\hline
\end{tabular}

Source: Reference [14]

Table 9. Comparison of physical parameters of soil under organic vs conventional management in EFY and yams

At present, deficiency of secondary and micro-nutrients ( $\mathrm{Zn}, \mathrm{S}, \mathrm{B}, \mathrm{Mo}, \mathrm{Fe}, \mathrm{Mn}$ and $\mathrm{Cu}$ ) is a rampant soil problem affecting crop productivity and profitability of farming in India $[5,12]$. This is mainly due to the continuous use of high analysis fertilizers, which do not provide secondary and micro-nutrients. Based on research conducted for a decade in these crops, it has been proved beyond doubt that organic farming helps to reinstate soil productivity. Organic agriculture that envisages elimination of synthetic chemical fertilizers through strict use of organic manures helps to refurbish the soil health, by improving organic matter, neutralizing soil acidity, supplying almost all essential nutrients in the available form and ultimately conserving soil fertility $[3,5,12]$. 


\begin{tabular}{lllll}
\hline Physical parameters & \multicolumn{3}{c}{ Taro } \\
\cline { 2 - 5 } & Organic & Conventional & CD (0.05) & $\begin{array}{c}\text { \% increase or } \\
\text { decrease }\end{array}$ \\
\hline Bulk density $\left(\mathrm{g} \mathrm{cm}^{-3}\right)$ & 1.72 & 1.74 & NS & -1.38 \\
\hline Particle density $\left(\mathrm{g} \mathrm{cm}^{-3}\right)$ & 2.63 & 2.63 & NS & +0.26 \\
\hline Water-holding capacity $(\%)$ & 11.73 & 9.84 & NS & +19.20 \\
\hline Porosity $(\%)$ & 34.64 & 33.64 & NS & +2.97 \\
\hline
\end{tabular}

Table 10. Comparison of physical parameters of soil under organic vs conventional management in taro

\begin{tabular}{|c|c|c|c|c|c|c|c|c|}
\hline \multirow{2}{*}{$\begin{array}{l}\text { Chemical } \\
\text { parameters }\end{array}$} & \multicolumn{4}{|c|}{ EFY } & \multicolumn{4}{|c|}{ Yams } \\
\hline & Organic & Conventional & CD (0.05) & $\begin{array}{l}\% \text { increase } \\
\text { or decrease }\end{array}$ & Organic & Conventional & $\mathrm{CD}(0.05)$ & $\begin{array}{l}\% \text { increase } \\
\text { or decrease }\end{array}$ \\
\hline $\mathrm{pH}$ & 5.32 & 4.55 & 0.285 & +0.77 unit & 5.47 & 5.01 & 0.212 & +0.46 unit \\
\hline Organic C $(\%)$ & 1.40 & 1.18 & NS & +19.02 & 0.86 & 0.75 & NS & +14.00 \\
\hline $\begin{array}{l}\text { Available N } \\
\left(\mathrm{kg} \mathrm{ha}^{-1}\right)\end{array}$ & 125.60 & 103.30 & NS & +21.59 & 193.00 & 162.00 & NS & +19.14 \\
\hline $\begin{array}{l}\text { Available P } \\
\left(\mathrm{kg} \mathrm{ha}^{-1}\right)\end{array}$ & 65.20 & 57.30 & NS & +13.13 & 270.00 & 289.00 & NS & -6.57 \\
\hline $\begin{array}{l}\text { Available K } \\
\left(\mathrm{kg} \mathrm{ha}^{-1}\right)\end{array}$ & 362.00 & 340.90 & NS & +6.19 & 343.50 & 256.40 & 40.21 & +33.97 \\
\hline
\end{tabular}

Table 11. Comparison of chemical parameters of soil under organic vs conventional management in EFY and yams

The population of bacteria was considerably higher in organic plots than in conventional plots; 41 and 23\% higher in EFY and yams, respectively. Organic farming also favoured the fungal population by $17-20 \%$. While the $\mathrm{N}$ fixers showed an upper hand in organically managed soils by $10 \%$ over conventional management under EFY, P solubilizers remained more conspicuous under organic management of yams (22\% higher than conventional management) (Table 13). The dehydrogenase enzyme activity was higher by 23 and 14\% in organic plots in EFY and yams (Table 13).

In these studies, the organic resources used to replace chemical fertilizers were FYM, green manure, neem cake and ash. Green manuring with cowpea (incorporation of 15-20 $\mathrm{tha}^{-1}$ of green matter) was the most cost-effective component among these. The decomposition of these organic manures to release available plant nutrients involves intense microbial activity over chemical fertilizer-applied conventional plots. This might have resulted in higher microbial population and dehydrogenase enzyme activity in the organic plots. Several earlier workers also noticed increased microbial population in cultivated organically managed soil [3, 9, 60]. 


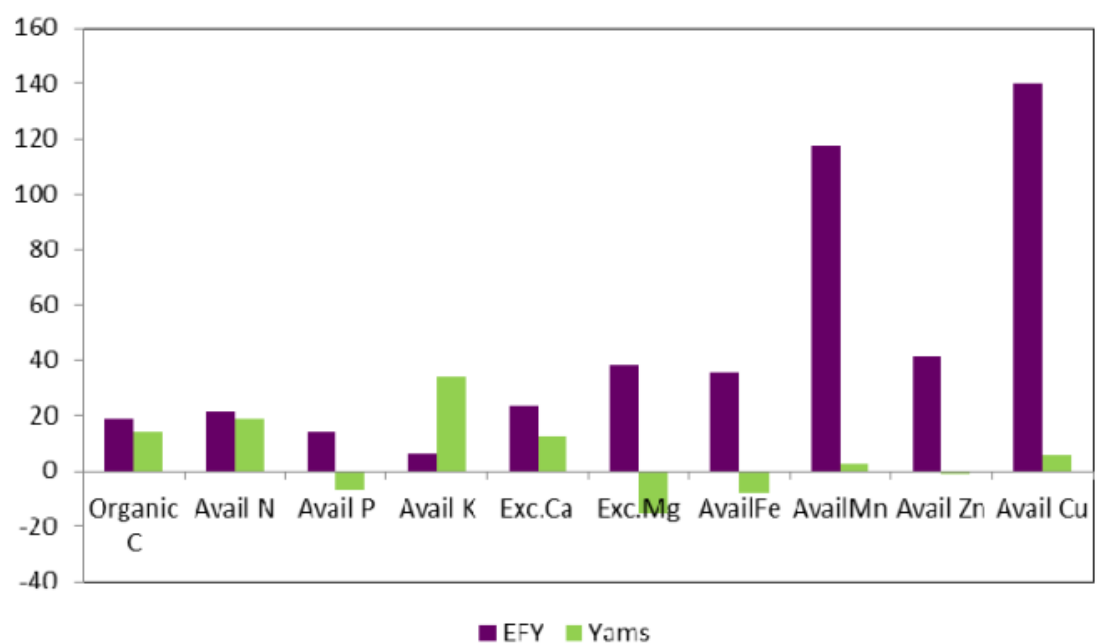

Figure 13. Per cent increase or decrease in chemical properties of soil under organic management in EFY and yams

\begin{tabular}{|c|c|c|c|c|c|c|c|c|}
\hline \multirow{2}{*}{$\begin{array}{l}\text { Chemical } \\
\text { parameters }\end{array}$} & \multicolumn{4}{|c|}{ Dwarf white yam } & \multicolumn{4}{|c|}{ Taro } \\
\hline & Organic & Conventional & $\begin{array}{l}\mathrm{CD} \\
(0.05)\end{array}$ & $\begin{array}{l}\% \text { increase or } \\
\text { decrease }\end{array}$ & Organic & Conventional & $\mathrm{CD}(0$. & $\begin{array}{l}\% \\
\text { increase or } \\
\text { decrease }\end{array}$ \\
\hline $\mathrm{pH}$ & 5.68 & 4.56 & 0.467 & +1.11 unit & 6.68 & 5.48 & 0.473 & +1.20 unit \\
\hline Organic C (\%) & 2.29 & 1.97 & NS & +16.46 & 0.84 & 0.60 & NS & +39.03 \\
\hline $\begin{array}{l}\text { Available N } \\
\left(\mathrm{kg} \mathrm{ha}^{-1}\right)\end{array}$ & 119.80 & 109.80 & NS & +9.11 & 105.00 & 103.50 & NS & +1.45 \\
\hline $\begin{array}{l}\text { Available P } \\
\left(\mathrm{kg} \mathrm{ha}^{-1}\right)\end{array}$ & 107.30 & 98.00 & NS & +9.49 & 75.10 & 47.10 & 20.34 & +59.44 \\
\hline $\begin{array}{l}\text { Available K } \\
\left(\mathrm{kg} \mathrm{ha}^{-1}\right)\end{array}$ & 453.00 & 312.00 & NS & +45.19 & 148.00 & 202.00 & NS & -26.73 \\
\hline
\end{tabular}

Table 12. Comparison of chemical parameters of soil under organic vs conventional management in dwarf white yam and taro

\subsubsection{Development of $S Q I$}

In EFY, the organic system scored a significantly higher SQI (1.930), closely followed by the traditional system (1.913) (Figure 14). The SQI of conventional (1.456) and biofertilizer systems (1.580) were significantly lower. The SQI was driven by water-holding capacity, $\mathrm{pH}$ and available $\mathrm{Zn}$ followed by SOM. 


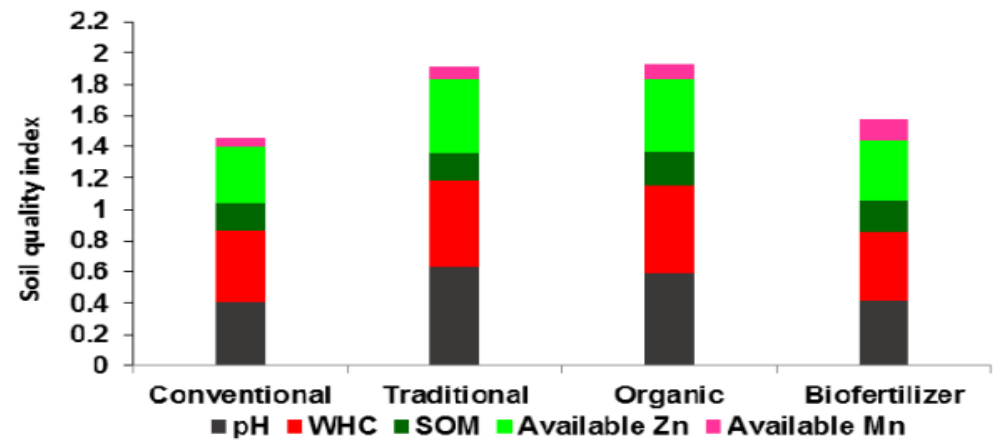

Figure 14. Effect of production systems on SQI in EFY (Source: Reference [13])

\begin{tabular}{|c|c|c|c|c|c|c|c|c|}
\hline \multirow{2}{*}{$\begin{array}{l}\text { Biological } \\
\text { Parameters }\end{array}$} & \multicolumn{4}{|c|}{ EFY } & \multicolumn{4}{|c|}{ Yams } \\
\hline & Organic & Conventional & $\begin{array}{l}\text { CD } \\
(0.05)\end{array}$ & $\begin{array}{l}\text { Per cent } \\
\text { increase (+) } \\
\text { or decrease } \\
(-) \text { in } \\
\text { organic } \\
\text { farming }\end{array}$ & Organic & Conventional & CD (0.05) & $\begin{array}{l}\text { Per cent } \\
\text { increase }(+) \\
\text { or decrease } \\
(-) \text { in } \\
\text { organic } \\
\text { farming }\end{array}$ \\
\hline $\begin{array}{l}\text { Bacteria }\left(\mathrm{cfu} \mathrm{g}^{-1}\right. \\
\text { soil) }\end{array}$ & $31 \times 10^{7}$ & $22 \times 10^{7}$ & NS & +40.90 & $118 \times 10^{3}$ & $96 \times 10^{3}$ & NS & +22.91 \\
\hline $\begin{array}{l}\text { Fungi (cfu g-1 } \\
\text { soil) }\end{array}$ & $6 \times 10^{6}$ & $5 \times 10^{6}$ & NS & +20.00 & $7 \times 10^{2}$ & $6 \times 10^{2}$ & NS & +16.66 \\
\hline $\begin{array}{l}\text { Actinomycetes } \\
\text { (cfu g }{ }^{-1} \text { soil) }\end{array}$ & $22 \times 10^{5}$ & $24 \times 10^{5}$ & NS & -8.33 & $11 \times 10^{3}$ & $12 \times 10^{3}$ & 4.682 & -8.33 \\
\hline $\begin{array}{l}\text { N fixers } \\
\left(\mathrm{cfu} \mathrm{g}^{-1} \text { soil) }\right.\end{array}$ & $182 \times 10^{5}$ & $165 \times 10^{5}$ & NS & +10.30 & $7 \times 10^{3}$ & $11 \times 10^{3}$ & NS & -36.36 \\
\hline $\begin{array}{l}\text { P solubilizers } \\
\text { (cfu g }{ }^{-1} \text { soil) }\end{array}$ & $5 \times 10^{6}$ & $5 \times 10^{6}$ & NS & 0 & $11 \times 10^{3}$ & $9 \times 10^{3}$ & NS & +22.22 \\
\hline $\begin{array}{l}\text { Dehydrogenase } \\
\text { enzyme ( } \mu \mathrm{g} \\
\text { TPF formed g } \\
\text { soil } \mathrm{h}^{-1} \text { ) }\end{array}$ & 1.625 & 1.323 & NS & +22.82 & 1.174 & 0.786 & NS & +49.36 \\
\hline
\end{tabular}

Source: Reference [14]

Table 13. Comparison of biological parameters of soil under organic vs conventional management in EFY and yams 
Soil quality is the capacity of a soil to function within natural or managed ecosystem boundaries to sustain plant and animal productivity in order to maintain or enhance water and air quality and support human health and habitation [61]. In this study, organic farming, which is a supplemental $\mathrm{C}$ management practice (SCMP) significantly changed a number of soil properties including soil $\mathrm{pH}, \mathrm{SOM}$, exchangeable $\mathrm{Mg}$, available $\mathrm{Cu}, \mathrm{Mn}$ and Fe contents and WHC. Thus, the indicator properties could be changed mainly through SOM building practices brought about by the strict use of organic manures especially green manuring continuously for five years under organic management. This framework emphasizes that soil quality assessment is a tool that can be used to evaluate the effects of land management on soil function.

\section{On-farm validation of organic production technologies}

Demonstration trials were conducted during 2008-2009 in 10 farmers' sites to cover an area of 5 ha in Kollam and Pathanamthitta districts of Kerala to compare the yield, quality, economics and soil fertility under the organic management practices with the existing farmers' practice and conventional practice (present package of practices recommendations) in EFY (Figure 15). Organic farming resulted in higher corm yield ( $\left.34.60 \mathrm{t} \mathrm{ha}^{-1}\right)$ and additional income (Rs. $43,651 \mathrm{ha}^{-1}$ ) over conventional farming. Organically produced corms had significantly higher dry matter and $\mathrm{Mg}$ contents and significantly lower oxalate content. The chemical properties of the soil, especially K, was seen to be favoured under organic farming (Table 14).

\begin{tabular}{|c|c|c|c|c|c|c|c|}
\hline $\begin{array}{l}\text { Production } \\
\text { systems }\end{array}$ & Yield $\left(\mathrm{t} \mathrm{ha}^{-1}\right)$ & $\begin{array}{l}\text { Corm dry matter } \\
(\%)\end{array}$ & $\begin{array}{l}\text { Oxalate } \\
\text { (DW basis \%) } \\
\text { content of } \\
\text { corms }\end{array}$ & $\begin{array}{l}\text { Mg content } \\
\text { of corms } \\
(\mathrm{mg} 100 \mathrm{~g})\end{array}$ & $\begin{array}{l}\text { Available K } \\
\text { of soil (kg ha } \\
\left.{ }^{-1}\right)\end{array}$ & $\begin{array}{l}\text { Net income } \\
\left(\mathrm{Rs} \mathrm{ha}^{-1}\right)\end{array}$ & B:C ratio \\
\hline Conventional & 24.50 & 19.29 & 0.221 & 91.90 & 98.80 & 70,069 & 1.40 \\
\hline Traditional & 22.20 & 20.00 & 0.218 & 91.80 & 88.70 & 41,925 & 1.23 \\
\hline Organic & 34.60 & 21.00 & 0.191 & 95.30 & 142.70 & $1,13,720$ & 1.49 \\
\hline CD (0.05) & 7.750 & 1.162 & 0.0076 & 2.045 & 40.02 & & \\
\hline
\end{tabular}

Source: Reference [11]

Table 14. Agronomic, nutritional and economic implications of organic management in EFY under validation trials

OFT were laid out in seven sites with three practices, conventional, traditional and organic, in Thiruvananthapuram and Kollam districts of Kerala to validate the on-station-developed organic farming technologies in yams (greater yam, lesser yam and dwarf white yam) and taro (Figure 15). In all sites, tuber yield under organic management was on a par with conventional practice in these crops (Figure 16). However, the yields under organic management were 8, 17, 21 and 29\% higher over chemical-based farming in greater yam, lesser yam, dwarf white yam and taro, respectively. In general, there was significant improvement in $\mathrm{pH}$, organic $\mathrm{C}$ 
and available K status under organic management in the sites. Soil microbial population was also improved under organic practice in these sites.
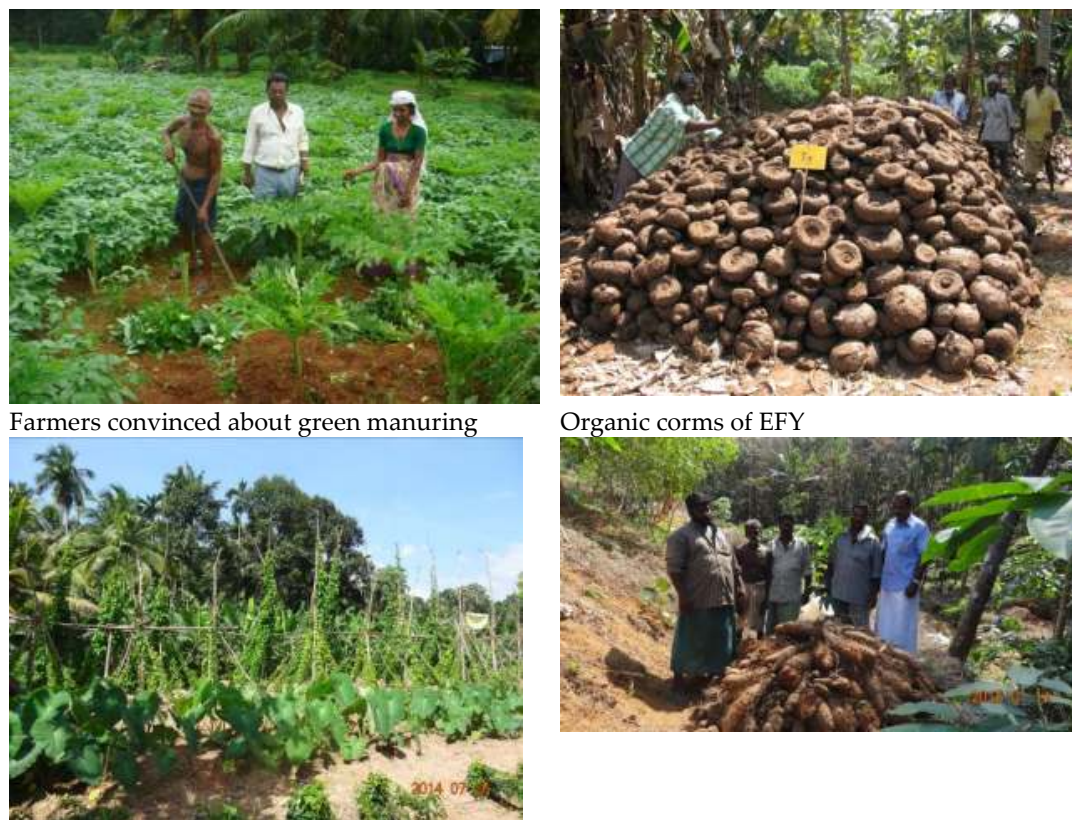

Organic corms of EFY

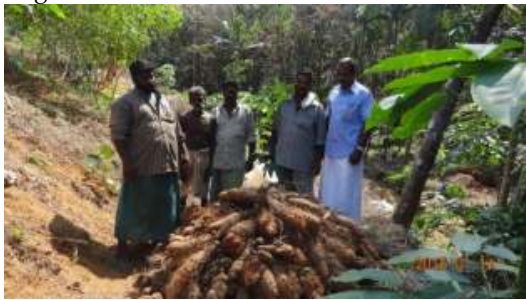

View of OFT on yams and taro

Farmers with organic tubers of greater yam

Figure 15. On-farm validation trials conducted in Kerala

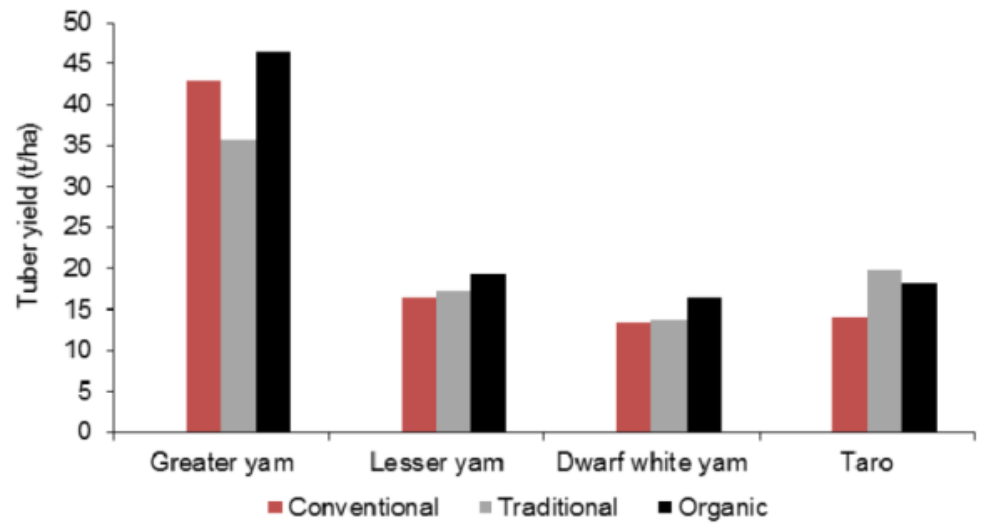

Figure 16. Yield under various practices in OFT in yams and taro 


\section{The package}

Use of organically produced seed materials, seed treatment in cow-dung, neem cake, bioinoculant slurry, FYM incubated with bio-inoculants, green manuring, use of neem cake, biofertilizers and ash formed the strategies for organic production (Figure 17). The organic farming package for EFY is included in the Package of Practices Recommendations for crops by Kerala Agricultural University [62].

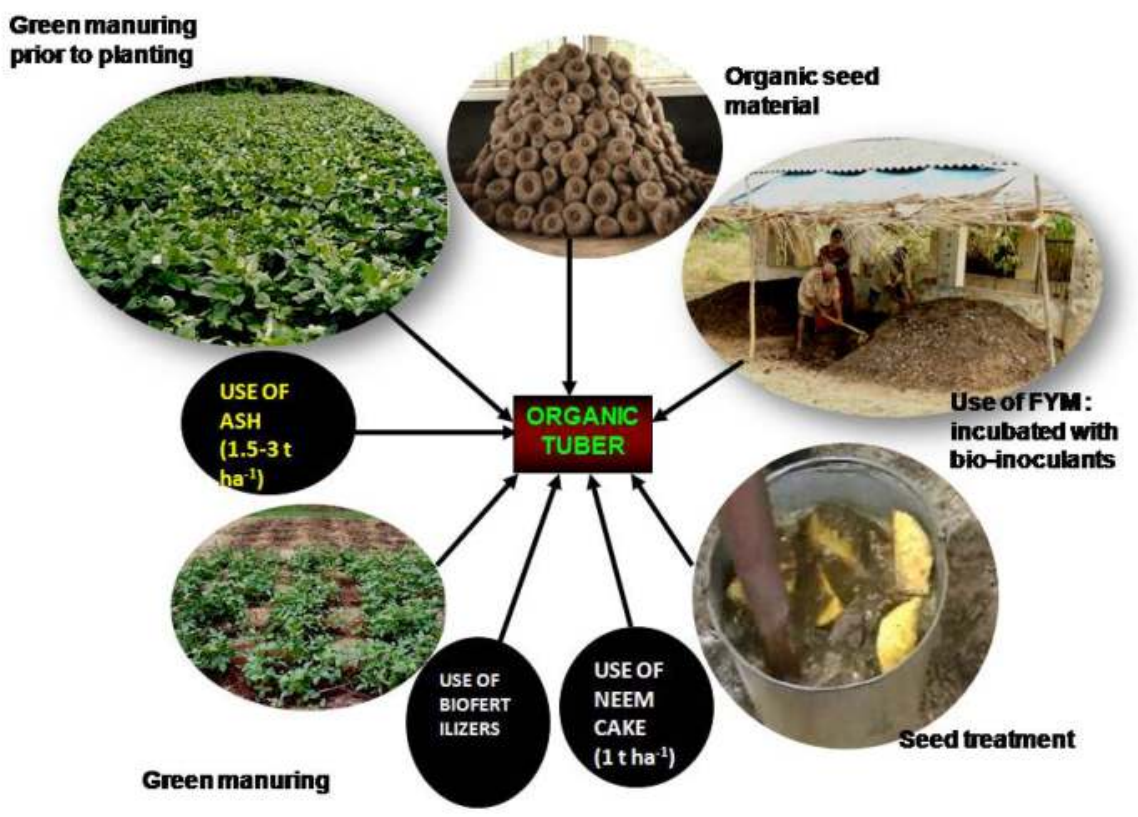

Figure 17. Essential components of organic tuber production

\section{Development of a learning system}

A learning system was developed using ANN to predict the performance of EFY production system. A three-layered system with one input layer, one output layer and one hidden layer was developed. The input layer neurons included temperature, rainfall, planting material, FYM, potassium, phosphorus, ash, neem cake, Azospirillum, phosphobacteria, mycorrhiza and green manure. The output layer neurons were total biomass, corm yield, canopy spread and plant height. 


\subsection{Structure of the system}

A three-layered feed-forward back-propagation network (FFBPN) (Figure 18) was designed for this learning system [41]. Its block diagram (Figure 19) explains the flow of the inputs and the modifications made on it while it passes through the different layers before the output is generated.

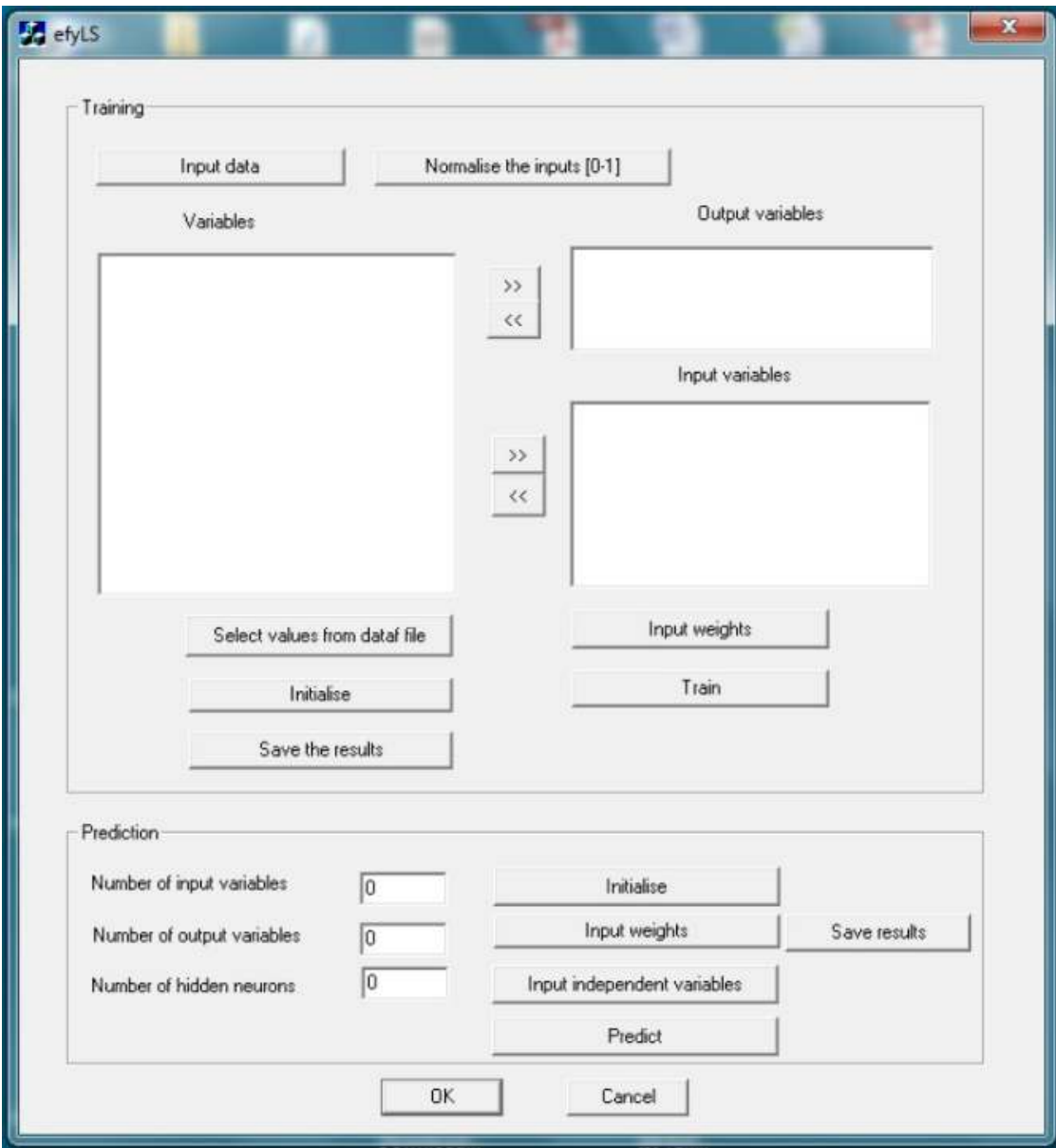

Figure 18. Learning system to predict the performance of EFY production system

Input layer of the network is composed of 12 neurons represented by I1, I2,..., I12. The activities of neurons in the input layer represent the raw information that is fed into the network. Inputs added to the neurons of the input layer are given in Table 15. 


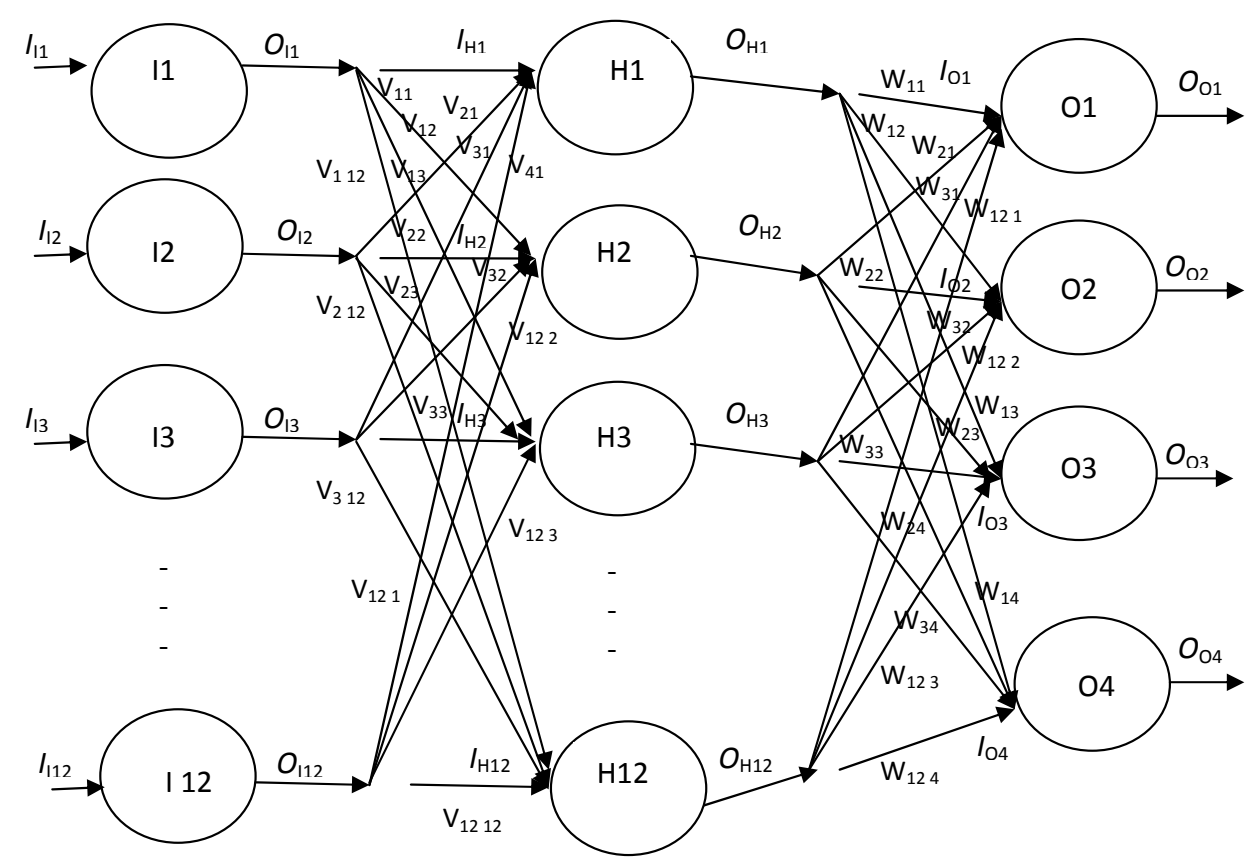

Figure 19. Structure of the three-layered FFBPN of the learning system

\begin{tabular}{lll}
\hline Sl. No. & Inputs added & Neuron of the input layer \\
\hline 1. & Temperature $\left({ }^{\circ} \mathrm{C}\right)$ & $\mathrm{I} 1$ \\
\hline 2. & Rainfall $(\mathrm{mm})$ & $\mathrm{I} 2$ \\
\hline 3. & Planting material $(\mathrm{kg})$ & $\mathrm{I} 3$ \\
\hline 4. & Farmyard manure $(\mathrm{kg})$ & $\mathrm{I} 4$ \\
\hline 5. & Potassium $(\mathrm{kg})$ & $\mathrm{I} 5$ \\
\hline 6. & Phosphorus $(\mathrm{kg})$ & $\mathrm{I} 6$ \\
\hline 7. & Ash $(\mathrm{kg})$ & $\mathrm{I} 7$ \\
\hline 8. & Neem cake $(\mathrm{kg})$ & $\mathrm{I} 8$ \\
\hline 9. & Azospirillum $(\mathrm{kg})$ & $\mathrm{I} 9$ \\
\hline 10. & Phosphobacteria $(\mathrm{kg})$ & $\mathrm{I} 10$ \\
\hline 11. & Mycorrhiza $(\mathrm{kg})$ & $\mathrm{I} 11$ \\
\hline 12. & Green manure $(\mathrm{kg})$ & $\mathrm{I} 12$ \\
\hline
\end{tabular}

Table 15. List of inputs added to various neurons in the input layer of the FFBPN 
As linear activation function is operating in the input layer of the network, the input (I) and output $(\mathrm{O})$ of the input layer are the same:

$$
\{O\}_{t}=\{I\}_{t}
$$

The hidden neurons $\mathrm{H} 1 \ldots \mathrm{H} 12$ are connected by synapse to the input neurons. Let $\mathrm{V}_{m, p}$ be the weight of the arc between $m$ th input neuron and the $p$ th hidden neuron. The input to the hidden neuron is the weighted sum of the outputs of the input neurons to get $\mathrm{I}_{H p}$, i.e. the input to the $p$ th hidden neuron as

$$
I_{H p}=\sum_{m=1, p=1}^{12,12} V_{m, p} O_{I, m}
$$

where

$\mathrm{O}_{I, m}$ is the output of $m$ th input neuron.

In the hidden neurons, sigmoidal function is operating and thus the output of the $p$ th hidden neuron is given by

$$
O_{H p}=\frac{1}{\left(1+e^{-\lambda\left(I_{H p}-\theta_{H p}\right)}\right)}
$$

where

$\mathrm{O}_{H p}$ is the output of the $p$ th hidden neuron

$\mathrm{I}_{\mathrm{Hp}}$ is the input of the $p$ th hidden neuron and

$\theta_{H p}$ is the threshold of the $p$ th hidden neuron, which is initialized to zero in this system

Input to the output neurons is the weighted sum of the outputs of the hidden neurons. Input to the $q$ th output neuron $\mathrm{I}_{O q}$ is calculated as follows:

$$
I_{\mathrm{O} q}=\sum_{n=1, q=1}^{12,4} W_{n, q} O_{H, n}
$$

where

$\mathrm{O}_{\mathrm{Hn}}$ is the output of the $n$th hidden neuron and

$\mathrm{W}_{n, q}$ is the weight of the arc between $n$th hidden neuron and $q$ th output neuron.

Sigmoidal function is operating in the output neurons also, and the output of the $q$ th neuron is given by 


$$
O_{O q}=\frac{1}{\left(1+e^{-\lambda\left(I_{O_{q}}-\theta_{O q}\right)}\right)}
$$

where

$\mathrm{O}_{O q}$ is the output of the $q$ th output neuron

$\mathrm{I}_{O q}$ is the input of the $q$ th output neuron and

$\theta_{O q}$ is the threshold of the $q$ th output neuron which is initialized to zero in this system

\subsection{Training of the system}

A three-layered FFBPN was designed for this learning system. Three years data (Table 16) on various aspects of cultivation of EFY were used for training the system.

\begin{tabular}{|c|c|c|c|c|}
\hline \multirow{2}{*}{ Inputs } & \multirow{2}{*}{ Input neuron } & \multicolumn{3}{|c|}{ Years } \\
\hline & & 2004 & 2005 & 2006 \\
\hline Temperature $\left({ }^{\circ} \mathrm{C}\right)$ & I1 & 27.91 & 28.68 & 27.91 \\
\hline Rainfall (mm/season) & I2 & $2,179.90$ & $1,862.95$ & $2,082.45$ \\
\hline Planting material (kg) & I3 & 750 & 750 & 750 \\
\hline FYM $\left(\mathrm{t} \mathrm{ha}^{-1}\right)$ & I4 & 25 & 25 & 25 \\
\hline Nitrogen $\left(\mathrm{kg} \mathrm{ha}^{-1}\right)$ & I5 & 100 & 100 & 100 \\
\hline Phosphorus (kg ha-1) & I6 & 50 & 50 & 50 \\
\hline Potassium (kg ha $\left.{ }^{-1}\right)$ & I7 & 150 & 150 & 150 \\
\hline Ash $\left(\mathrm{kg} \mathrm{ha}^{-1}\right)$ & I8 & 0 & 0 & 0 \\
\hline Neem cake $\left(\mathrm{kg} \mathrm{ha}^{-1}\right)$ & I9 & 0 & 0 & 0 \\
\hline Azospirillum $\left(\mathrm{kg} \mathrm{ha}^{-1}\right)$ & $\mathrm{I} 10$ & 0 & 0 & 0 \\
\hline Phosphobacteria $\left(\mathrm{kg} \mathrm{ha}^{-1}\right)$ & I11 & 0 & 0 & 0 \\
\hline Mycorrhiza $\left(\mathrm{kg} \mathrm{ha}^{-1}\right)$ & I12 & 0 & 0 & 0 \\
\hline Outputs & Output neuron & 2004 & 2005 & 2006 \\
\hline Total biomass (kg plant ${ }^{-1}$ ) & $\mathrm{O} 1$ & 3.48 & 3.19 & 3.14 \\
\hline Corm yield (kg plant ${ }^{-1}$ ) & $\mathrm{O} 2$ & 2.95 & 2.83 & 2.93 \\
\hline Canopy spread $\left(\mathrm{cm}_{\text {plant }}{ }^{-1}\right)$ & O3 & 110.37 & 111.61 & 101.18 \\
\hline Plant height ( $\mathrm{cm}$ plant ${ }^{-1}$ ) & $\mathrm{O} 4$ & 55.87 & 62.54 & 48.72 \\
\hline
\end{tabular}

Table 16. Values used for training the learning system 
Weight matrix obtained between input and hidden layers and between hidden and output layers is stored in the database and is used for making predictions with other input data-sets. This system learns about the EFY production system when the independent variables like weather parameters, soil and nutritional parameters of the system as well as the corresponding dependent variables of the system like com yield, canopy size, etc., are fed as input into it. Once it learns about a particular system pattern, it can predict the outputs corresponding to another set of independent variables of a similar pattern. The system can be trained for various independent-dependent variable patterns so that dependent variables for another set of same independent variables can be predicted accurately. When more and more inputs are used for training as well as prediction, the system learns more and its precision increases.

\section{Constraints in promotion of organic farming}

In India, the availability of organic manures is a major constraint. It is estimated that to feed 1.4 billion population by the year 2025, a minimum of 301 million tonnes of food grains are needed. To meet this demand, it will be necessary to harness 30-35 million tonnes of NPK from fertilizer carriers and an additional 10 million tonnes from organic and biofertilizer sources [63]. Thus, only approximately 25-30\% nutrient needs of Indian Agriculture can be met by utilizing organic sources solely [24,64]. Organic manures are bulky (high cost of handling and transportation), of low analysis, slowly available and variable in composition. The availability of cattle dung for organic farming will be further limited as this is a major source of fuel in rural households. Apart from these, green manuring and recycling of farm wastes as manures have not become popular as these are more time and space consuming and their impacts on productivity are not rapidly discernible. At present, certification procedures are cumbersome and expensive [24, 64].

\section{Future thrust}

Some of the future lines of action for promotion of organic farming have been identified [24, $64,65]$. Proper delineation and identification of prospective areas and crops (like tuber crops) may be helpful for effective promotion of organic farming. There is a need to undertake systematic research on the comparative values/advantages of organic farming over conventional farming on a long-term basis for promotion of organic farming. The package of practices recommendations for organic farming has to be popularized. The extent of availability of potential organic sources needs to be ascertained along with measures that may be helpful in improving the convenience of their use. Environmental impact, especially water and air quality effects, of organic farming needs to be assessed.

Weed management options particularly under climate change by nonchemical and biological methods are limited and need evaluation. The benefits accruing through organic farming on crop yield, quality, market preference and price advantage may be properly understood and promoted among the farmers and consumers [24]. 


\section{Conclusions}

In order to attain sustainable food-cum-livelihood-cum-environmental security in India, we may require an array of alternatives to chemical intensive agriculture. Instead of seriously debating on organic vs conventional agriculture it is better to examine critically the costs and benefits of the different alternative management options. It has been conclusively proved in tuber crops that organic management is an alternative viable option for sustainable and safe food production with less soil degradation and environmental pollution. Tuber crops, especially EFY and yams are prospective candidates for organic farming. EFY is the most responsive, followed by greater yam, white yam, lesser yam and taro. Generation of sufficient biomass, addition of crop residues, green manuring, farm waste recycling, fortification of manures through proper composting, adoption of crop rotations involving legumes, establishment of biogas plants and development of agro-forestry for alternate source of fuels are some of the strategies that will help promote organic farming of tuber crops. These practices would help a great deal in supplementing/rationalizing the use of inorganic fertilizers, which cannot be totally eliminated in Indian Agriculture.

\section{Author details}

Suja Girija, Sreekumar Janardanan, Jyothi Alummoottil Narayanan and Santosh Mithra Velayudhan Santhakumari

*Address all correspondence to: sujagin@yahoo.com

ICAR-Central Tuber Crops Research Institute, Thiruvananthapuram, Kerala, India

\section{References}

[1] Carter ME, Gamez R, Gliessman S. Sustainable Agriculture and the Environment in the Humid Tropics. Washington, DC: National Academy Press; 1993. 191 p.

[2] The Hindu. Climate change could trigger global food crisis. In: The Hindu. 1 September 2007. Op-Ed-pp.11.

[3] Suja G, Sreekumar J. Implications of organic management on yield, tuber quality and soil health in yams in the humid tropics. International Journal of Plant Production. 2014; 8(3): 291-309.

[4] Susan Andrews S, Mitchell JP, Mancinelli R, Karlen DL, Hartz TK, Horwath WR, Pettygrove GS, Scow KM, Munk DS. On-farm assessment of soil quality in California's central valley. Agronomy Journal. 2002; 94: 12-23. 
[5] Chhonkar PK. Organic farming and its relevance in India. In: Tarafdar JC, Tripathi KP, Mahesh K, editors. Organic Agriculture. Jodhpur: Scientific Publishers; 2008. pp. 5-33.

[6] Katsvairo TW, Wright DL, Marois JJ, Rich JR. Transition from conventional farming to organic farming using bahiagrass. Journal of the Science of Food and Agriculture. 2007; 87: 2751-2756.

[7] Rembialkowska E. Quality of plant products from organic agriculture. Journal of the Science of Food and Agriculture. 2007; 87: 2757-2762.

[8] Reganold JP, Glover JDP, Andrews K, Hinman HR. Sustainability of three apple production systems. Nature. 2001; 410: 926-929.

[9] Stockdale EA, Lampkin NH, Hovi M, Keating R, Lennartsson EKM, Macdonald DW, Padel S, Tattersall FH, Wolfe MS, Watson CA. Agronomic and environmental implications of organic farming systems. Advances in Agronomy. 2001; 70: 261-327.

[10] Suja G, Susan John K, Sundaresan S. Potential of tannia (Xanthosoma sagittifolium L.) for organic production. Journal of Root Crops. 2009; 35(1): 36-40.

[11] Suja G, Susan John K, Ravindran CS, Prathapan K, Sundaresan S. On farm validation of organic farming technology in elephant foot yam (Amorphophallus paeoniifolius Dennst. Nicolson). Journal of Root Crops. 2010; 36: 59-64.

[12] Suja G, Sundaresan S, Susan John K, Sreekumar J, Misra RS. Higher yield, profit and soil quality from organic farming of elephant foot yam. Agronomy for Sustainable Development. 2012a; 32: 755-764. DOI:10.1007/s13593-011-0058-5.

[13] Suja G, Sreekumar J, Susan John K, Sundaresan S. Organic production of tuberous vegetables: Agronomic, nutritional and economic benefits. Journal of Root Crops. 2012b; 38(2): 135-141.

[14] Suja G. Comparison of tuber yield, nutritional quality and soil health under organic versus conventional production in tuberous vegetables. Indian Journal of Agricultural Sciences. 2013; 83(11): 35-40.

[15] Branca G, Lipper L, McCarthy N, Jolejole MC. Food security, climate change, and sustainable land management. A review. Agronomy for Sustainable Development. 2013; 33: 635-650.

[16] UNFPA. The state of the world population report. By choice, not by chance: family planning, human rights and development. New York, NY: United Nations Population Fund; 2012.

[17] IAASTD. Agriculture at the crossroads. International Assessment of Agricultural Knowledge, Science and Technology for Development. Washington, DC: Island Press; 2009. 
[18] Tilman D, Cassman KG, Matson PA, Naylor R, Polasky S. Agricultural sustainability and intensive production practices. Nature. 2002; 418: 671-677. DOI:10.1038/ nature01014.

[19] Lal R. Degradation and resilience of soils. Philosophical Transactions of the Royal Society of London B. 1997; 352: 869-889. DOI:10.1098/rstb.1997.0078.

[20] World Bank. Sustainable land management: challenges, opportunities, and tradeoffs. Washington, DC: The World Bank; 2006.

[21] Woodfine A. The potential of sustainable land management practices for climate change mitigation and adaptation in sub-Saharan Africa. Rome: Food and Agriculture Organization of the United Nations; 2009.

[22] Pretty JN. Agricultural sustainability: concepts, principles and evidence. Philosophical Transactions of the Royal Society of London B. 2008; 363(1491): 447-466. DOI: 10.1098/rstb.2007.2163.

[23] Pretty JN. Editorial: sustainable intensification in Africa. International Journal of Agricultural Sustainability. 2011; 9(1): 3-4. DOI:10.3763/ijas.2010.0583.

[24] Suja G. Strategies for organic production of tropical tuber crops. In: Venkateswarlu B, Balloli SS, Ramakrishna YS, editors. Organic Farming in Rainfed Agriculture: Opportunities and Constraints. Hyderabad: Central Research Institute for Dryland Agriculture; 2008. pp. 135-143

[25] Das S, Biswas BC. Organic farming-prospects and problems. Fertilizer News. 2002; 47(12): 105-112, 115-118.

[26] Susan John K, Mohankumar CR, Ravindran CS, Prabhakar M. Long term effects of manures and fertilizers on cassava production and soil productivity in an acid ultisol. In: Proceedings National Workshop on Long Term Soil Fertility Management through Integrated Plant Nutrient Supply; 21-25 June 1998; Bhopal, India; 1998. pp. 318-325.

[27] Ravindran CS, Bala N. Effect of FYM and NPK on the yield and quality of sweet potato. Journal of Root Crops. 1987; 13(1): 35-39.

[28] Suja G. 2001. Resource management for intercropping white yam (Dioscorea rotundata Poir.) in coconut garden. [Ph.D. thesis]. Thrissur: Kerala Agricultural University; 2001. 195 p.

[29] Nayar TVR, Suja G. Organic production potential of tropical tuber crops. In: Abstracts XIV Swadeshi Science Congress; 5-7 November 2004; Kochi: Swadeshi Science Movement; 2004. pp. 20-21.

[30] AOAC. Official Methods of Analysis. Washington, DC: Association of Official Agricultural Chemists; 1980. pp. 169, 611-612, 1141. 
[31] Dubois M, Gilles KA, Hamilton JK, Rebers PA, Smith F. Colorimetric method for determination of sugars and related substances. Analytical Chemistry. 1956; 28: 350356.

[32] Nelson N. A photometric adaptation of the Somogyi method for determination of glucose. Journal of Biology and Chemistry.1944; 153: 375-380.

[33] Swain T, Hillis WE. The phenolic constituents of Prumus domestica 1. The quantitative analysis of phenolic constituents. Journal of the Science of Food and Agriculture. 1955; 10: 963-968.

[34] Piper, CS. Plant and Soil Analysis. Bombay: Hans Publications; 1970.

[35] Page AL, Miller RH, Keeney DR. Methods of Soil Analysis, Part 2: Chemical and Microbiological Properties, Agronomy Series No. 9, Madison, WI: American Society of Agronomy, Soil Science Society of America; 1982. 1159 p.

[36] Gupta RP, Dakshinamoorthy C. Procedures for Physical Analysis of Soil and Collection of Agrometeorological Data. New Delhi: Indian Agricultural Research Institute; 1980.

[37] Timonin MI. The interaction of higher plants and soil microorganisms I. Microbial population of the rhizosphere of seedlings of certain cultivated plants. Canadian Journal of Research. 1940; 181: 307-317.

[38] Klein DA, Loh TC, Goulding RL. A rapid procedure to evaluate dehydrogenase activity of soils low in organic matter. Soil Biology and Biochemistry. 1971; 3: 385-387.

[39] Karlen DL, Stott DE. A framework for evaluating physical and chemical indicators of soil quality. In: Doran JW, Coleman DC, Bezdicek DF, Stewart BA, editors. Defining Soil Quality for a Sustainable Environment. SSSA Special Publication No. 35. Madison, WI: Soil Science Society of America; 1994. pp. 53-72.

[40] SAS. SAS Users Guide. Cary, NC: SAS Institute Inc.; 2008.

[41] Frank Z, David B. Plant growth model using artificial neural networks. 1997. http://rs new.jpl.nasa.gov/dspace/bitstream/2014/22170/1/97-0632.pdf

[42] Rajasekaran S, Vijayalakshmi Pai GA. Neural Networks, Fuzzy Logic and Genetic Algorithms Synthesis and Applications. Delhi: PHI Publications; 2009.

[43] Ponti TD, Rijk B, van Ittersum MK. The crop yield gap between organic and conventional agriculture. Agricultural Systems. 2012; 108: 1-9.

[44] Seufert V, Ramankutty N, Foley JA. Comparing the yields of organic and conventional agriculture. Nature. 2012; 485: 229-232.

[45] Ramesh P, Mohan S, Subha Rao A. Organic farming: its relevance to the Indian context. Current Science. 2005; 88: 561-568. 
[46] Ramesh P, Panwar NR, Singh AB, Ramana S, Yadav SK, Shrivastava R, Subha Rao A. Status of organic farming in India. Current Science. 2010; 98: 1190-1194.

[47] Suja G, Santhosh Mithra VS, Sreekumar J, Jyothi AN. Is organic tuber production promising? Focus on implications, technologies and learning system development. In: Rahmann G, Aksoy U, editors. Proceedings of the 4th ISOFAR Scientific Conference. 'Building Organic Bridges'. Organic World Congress; 13-15 October 2014; Istanbul, Turkey; 2014. eprint ID 23666.

[48] Stanhill G. The comparative productivity of organic agriculture. Agriculture Ecosystem and Environment. 1990; 30: 1-26.

[49] Offermann F, Nieberg H. Economic performance of organic farms in Europe. In: Organic Farming in Europe: Economics and Policy, vol. 5. Hohenheim: University of Hohenheim; 1999.

[50] Clark MS, Horwath WR, Shennan C, Scow KM. Changes in soil chemical properties resulting from organic and low-input farming systems. Agronomy Journal. 1998; 90: 662-671.

[51] Colla G, Mitchell JP, Joyce BA, Huyck LM, Wallender W, Temple SR, Hsiao TC, Poudel DD. Soil physical properties and tomato yield and quality in alternative cropping systems. Agronomy Journal. 2000; 92: 924-932.

[52] Kabeerathumma S, Mohan Kumar B, Nair PG. Nutrient uptake and their utilization by yams, aroids and coleus. Technical Bulletin Series No. 10. Thiruvananthapuram: Central Tuber Crops Research Institute; 1987.

[53] Pieper JR, Barrett DM. Effects of organic and conventional production systems on quality and nutritional parameters of processing tomatoes. Journal of the Science of Food and Agriculture. 2008; 89: 177-194.

[54] Worthington V. Nutritional quality of organic versus conventional fruits, vegetables and grains. The Journal of Alternative and Complementary Medicine. 2001; 7(2): 161173.

[55] Droogers P, Fermont A, Bouma J. Effects of ecological soil management on workability and trafficability of a loamy soil in the Netherlands. Geoderma. 1996; 73: 131-145.

[56] Gerhardt RA. A comparative analysis of the effects of organic and conventional farming systems on soil structure. Biological Agriculture Horticulture. 1997; 14: 139157.

[57] Mei C, Yahua S, Zhengguo O, Qirong S. Amelioration of aluminium toxicity with pig manure in an acid red soil. Plant Nutrition and Fertilizer Science. 2002; 8(2): 176.

[58] Prabhakaran C, Pitchai GJ. Effect of different organic nitrogen sources on $\mathrm{pH}$, total soluble solids, titrable acidity, reducing and non reducing sugars, crude protein and 
ascorbic acid content of tomato fruits. Journal of Soils and Crops. 2002; 12(2): 160166.

[59] Prakash YS, Bhadoria PBS, Rakshit A. Comparative efficacy of organic manures on the changes in soil properties and nutrient availability in an Alfisol. Journal of the Indian Society of Soil Science. 2002; 50(2): 219-221.

[60] Scow KM, Somasco O, Gunapala N, Lau S, Venette R, Ferris H, Miller R, Shenman C. Transition from conventional to low-input agriculture changes soil fertility and biology. California Agriculture. 1994; 48: 20-26.

[61] Karlen DL, Mausbach MJ, Doran JW, Cline RG, Harris RF, Sehuman GE. Soil quality: A concept, definition and framework for evaluation. Soil Science Society of America Journal. 1997; 61: 4-10.

[62] KAU. Package of Practices Recommendations: Crops. Thrissur: Kerala Agricultural University; 2011. pp. 49-50.

[63] NAAS. Fertilizer Policy Issues (2000-2025). Policy Paper 2. New Delhi: National Academy of Agricultural Sciences; 1997. 5 p.

[64] Chhonkar PK, Dwivedi BS. Organic farming and its implications on India's food security. Fertilizer News. 2004; 49(11): 15-18, 21-28, 31, 38.

[65] Marwaha BC, Jat SL. Status and scope of organic farming in India. Fertilizer News. 2004; 49(11): 41-48. 